Grant-in-Aid for Scientific Research (S)

Real Estate Markets, Financial Crisis, and Economic Growth

: An Integrated Economic Approach

Working Paper Series No.61

Impact of population aging on household savings and portfolio choice in Japan

\author{
Tokuo Iwaisako \\ Arito Ono \\ Amane Saito \\ and \\ Hidenobu Tokuda
}

September, 2016

HIT-REFINED PROJ ECT

Institute of Economic Research, Hitotsubashi University

Naka 2-1, Kunitachi-city, Tokyo 186-8603, J APAN

Tel: +81-42-580-9145

E-mail: hit-refined-sec @ier.hit-u.ac .jp

http://www.ier.hit-u.ac.jp/hit-refined/ 


\title{
Impact of population aging on household savings and portfolio choice in Japan*
}

\author{
Tokuo Iwaisako, Arito Ono, Amane Saito and, Hidenobu Tokuda
}

September 20, 2016

\begin{abstract}
We examine the impact of population aging on Japanese financial markets, particularly whether households have begun to dissave and reduce their asset holdings of risky assets, such as stocks, as a result. Our main finding is that there is currently no significant decline in stock holdings and that this trend will continue in the near future. While there is little doubt that Japanese household savings have decreased of late, we should view the sharp decline observed in the early 2000s as a deviation from the long-run trend associated with a large income shock. The true trend of savings without a negative income shock in the early 2000s would have been declining more smoothly and moderately, so that any abrupt portfolio shift associated with negative shocks to household savings is unlikely. As found in our previous work, the average share of risky assets in Japanese household portfolios increases with age and barely decreases, even for those aged 60 years and over. The decline in household stock holding will be slower than it could have been with comparable aging in other countries. According to our micro data (Nikkei Radar), the main sources of increasing household wealth are the increasing wealth of the elderly and the increasing proportion of the wealthier elderly population over the period 2000-14. Household portfolio shares have slowly moved from bank deposits to stocks; a change mostly explained by the increase in the proportion of elderly households holding stocks.

We also closely consider the effect of aging on the Japanese government bond (JGB) market in the new millennium. Household direct holdings of JGBs peaked around 2008-09. However, direct holdings of JGBs are very limited when compared with the total amount outstanding. Consequently, we expect that population aging will not exert a significant effect on the JGB market.

* Tokuo Iwaisako (Hitotsubashi University; corresponding author: iwaisako@ier.hit-u.ac.jp), Arito Ono (Chuo University), Amane Saito (Mizuho Research Institute), Hidenobu Tokuda (Mizuho Research Institute). This paper was prepared for NBER/ESRI International Conference 2016, Aging in Japan: The Impact of the Retirement of Japan's Baby Boomers in August 2 2016. We are particularly grateful to James Poterba for his comments, as well as the comments from other participants of the conference. Huan Li and Wakana Toyama provided able research assistance. We acknowledge the financial support from the Grant-in-Aid for Scientific Research (S), No. 25220502, JSPS. Iwaisako also acknowledges the support from Grant-in-Aid for Scientific Research (A) 25245037, JSPS, while Ono also acknowledges the support from Grant-in-Aid for Scientific Research 15H06619. The views expressed in this paper are ours and do not necessarily reflect any of the institutions with which we are affiliated.
\end{abstract}




\section{Introduction}

The Japanese economy faces a future with a rapidly aging population, with $26 \%$ of its people exceeding 65 years of age in 2015, the highest proportion in the world. By 2060, one in every two-and-a-half Japanese will be over 65 and one in four over the age of 75 (Cabinet Office 2015). ${ }^{1}$ This aging of Japanese society will certainly affect the economy in general, along with its financial system in particular. In this paper, we attempt to shed some light on the effect of this aging on Japan's asset markets.

The demographic impact of population aging on financial markets has attracted the attention of academics and practitioners alike. For example, whether changes in the population age distribution account for long-run cycles in the US stock market has been the subject of much attention. One commonly expressed view is that "...the aging of the baby boom cohort is a key factor in explaining the (recent) rise in asset values, and by predictions that asset prices will decline when this group reaches retirement age and begin to reduce its asset holdings" (Poterba 2001, p. 565). Past theoretical analysis of general equilibrium overlapping generations (OLG) models combined with calibration exercises suggest that the demography could certainly affect the rate of return on capital (Abel 2003; Geanakoplos et al. 2004). However, even though a number of studies, including Bakshi and Chen (1994) and Ang and Maddaloni (2005), assert that they find supportive evidence for the demographic impact on asset prices and/or returns, the overall empirical results are at best mixed (Poterba 2001). In addition, closed economy OLG models may not provide a very good description of Japanese financial markets today given that the influence of foreign investors in the Japanese market has increased in the post-bubble era, particularly in the 2000s and the 2010s. ${ }^{2}$

For these reasons, we pursue a more modest and focused goal in this paper. We examine recent changes in Japanese household portfolios along with changes in household savings and wealth in Japan. Following the recent empirical literature on housing portfolios, we examine whether the holding of risky assets, such as stocks, will fall as the process of population aging continues in Japan. For this purpose, we investigate

\footnotetext{
${ }^{1}$ Cabinet Office (2015), URL: http://www8.cao.go.jp/kourei/whitepaper/w-2015/html/gaiyou/s1_1.htm

${ }^{2}$ For example, Jiang et al. (2014) conclude that foreign institutions owned more than a quarter of Japanese equities (in terms of market capitalization) by the second half of the 2000s.
} 
recent changes in household demand for financial assets.

Our overall finding is that we have not yet observed any significant decline in stock holdings by Japanese households to date, and that we expect this trend to continue in the near-term future. The reasoning is as follows: First, we believe the dramatic decline in household savings in the early 2000s in Japan has exaggerated the impact of the population aging process. While there is no doubt that the Japanese household savings rate has decreased, we should view its decline at the beginning of the $2000 \mathrm{~s}$ as a deviation from a longer-run trend associated with a large negative income shock. The true trend of savings without a negative income shock in the early 2000s would have been declining more smoothly and moderately, so any abrupt portfolio shift owing to negative shocks to household savings and/or wealth is unlikely.

Second, as documented in our previous work, the average share of risky assets in Japanese household portfolios increases with age and barely decreases, even for persons aged 60 and over (Iwaisako 2009; Iwaisako, Mitchell, and Piggott 2005; Iwaisako et al. 2015). In contrast, the relationship between household age and the share of risky assets exhibits a clear hump-shape in the US and many western European countries (Ameriks and Zeldes 2004; Guiso et al. 2002). ${ }^{3}$ As a result, the decline in household stock holding in Japan will be slower than it would be if the same speed of aging took place in other OECD countries. In fact, according to our analysis of micro data on household portfolios (Nikkei Radar), the main sources of increasing household wealth in Japan are the increasing wealth of the elderly, those aged in their 50s and over 60 years, and the increasing population share of the wealthy elderly over the period 2000-14. In general, household portfolios move only slowly from bank deposits to stocks, and we largely explain this change by the increase in the number of elderly households holding stocks.

\section{Household, corporate, and national savings}

Before we examine the impact of population aging on Japanese household portfolios, in this section we provide an overview of Japan's household and private sector savings since the 1990s. The benchmark for any analyses of household saving and portfolio decisions

\footnotetext{
${ }^{3}$ In contrast, Poterba et al. (2015) finds that U.S. households seem to preserve their exposure to corporate stocks as they age.
} 
is the life-cycle model (Modigliani and Brumberg, 1954; Ando and Modigliani, 1963) which suggests that when a household retires from the workforce, it begins to dissave and shift its asset portfolio away from risky assets such as stocks to safer assets including government bonds and term deposits. Hence, by looking at the changes in household savings, we can infer whether the process of aging is having an impact on household financial decision-making. Further, we suspect that the sharp decline in Japanese household savings in the early 2000 s exaggerates the perception of urgency regarding the impact of the population aging process. We contend that we should instead view this period as a deviation from a longer-run trend associated with a large income shock.

\subsection{Household and corporate savings in the national accounts}

Figure 1 plots annual (fiscal year) household, corporate, and national savings and the current account balance in Japan as a percentage of GDP. Starting with household savings, we can see that savings declined significantly in the first half of the 2000s, particularly from 1999 to 2001. It then continued a mild downward trend between 2002 and 2005 and then stabilized, exhibiting no apparent upward or downward trend since at least the second half of the 2000s and during the 2010s, save a noticeable decline in 2013. We note that the consumption tax in Japan increased from 5\% to 8\% in April 2014. As the data in Figure 1 is on a fiscal year basis, April to March of the following year, we suggest the pre-tax hike in household expenditures explains the decline in household savings in 2013 and its subsequent rebound after April 2014.

As documented in Iwaisako and Okada (2012) among others, corporate savings increased steadily from 1998 to 2004, offsetting most of the decline in household saving. Corporate savings as the percentage of GDP have remained at a relatively high level of about 7\% of GDP for most of the period 2005-14. As a result, Japan's private-sector savings have only mildly decreased in the last two decades by about two percentage points. $^{4}$

[Figure 1]

\footnotetext{
${ }^{4}$ More precisely, the private sector in national account data also includes private non-profit institutions serving households as an institutional sector, in addition to corporate sector and household sector.
} 
National savings, or the sum of private sector and government savings, had been on a decreasing trend from 1994 to 2002. This reverted between 2003 and 2007 when the Japanese economy was on a mild path to economic recovery. It then declined significantly, first in 2008 and again in 2009, reflecting the large fiscal stimulus and the budget deficits following the onset of the Global Financial Crisis. Hence, we can attribute most of the decline in Japanese national savings in the last twenty years to a combination of a minor decreasing trend in private sector savings and the significant deterioration in general fiscal conditions.

These observations lead to some important questions regarding the interpretation of the movement of household and corporate savings in Japan. First, if Ricardian equivalence holds, distinguishing between private sector and government savings makes little sense. However, even if we do not literally assume public and private savings to be perfect substitutes, it is still important to question what could have happened to private sector savings if the fiscal stimulus responding to the Great Recession in Japan had been not as aggressive. Similarly, what would have happened if the implementation of the consumption tax rate hikes had been in a more orderly manner, particularly if the increase in the tax rate from $8 \%$ to $10 \%$ had not been postponed $?^{5}$ Clearly, in understanding recent household saving behavior, it is necessary to give due attention to the potential impact of government spending and (the absence or not of) tax changes.

An even subtler question concerns the substitution between household and corporate savings. Since the late 1990s, the Japanese corporate savings rate has been extremely high, even when compared with the post-Great Recession US, as plotted in Figure 2. However, we do not have a good theory concerning corporate savings. We could, of course, argue that the household sector ultimately owns all businesses in the private sector, so the two forms of savings are perfect substitutes. If we take this view of a "corporate veil" (Poterba 1987), then we inevitably conclude that there has been very little decline in private savings in Japan since the mid-1990s. If we do not, then the important question is whether if corporate savings start to decline and/or household incomes increases in the near future, will household savings also increase or remain unchanged.

\footnotetext{
5 Japanese consumption tax rate was raised from 5\% to 8\% in April 2014. At that time, a further increase from $8 \%$ to $10 \%$ had been scheduled in October 2015 . However, following a brief, but very severe recession in the summer /fall in 2014, in November, PM Abe decided to postpone the increase of tax rate until April 2017. In June 2016, he once again postponed the tax hike until October 2019.
} 
[Figure 2]

\subsection{Household savings rates in aggregate and semi-micro data}

In order to investigate the mechanism underpinning the aggregate dynamics of household savings, we examine the household survey data in the Family Income and Expenditure Survey (FIES) (Kakei-chosa in Japanese). Figure 3 illustrates the GDP savings rate and the FIES savings rate by calendar year over the period 1994-2015. As shown, and as is well known, there is a significant difference in the savings rates as calculated using the GDP and FIES data, with the latter being considerably higher over many years. ${ }^{6}$ However, while their respective savings levels are very different, their movements are somewhat similar, at least in our sample period, with large falls in both from the end of the 1990s up until 2004. Both savings rates were mostly flat after 2005, but with smaller declines in 2012, 2013, and 2014. Unfortunately, the GDP savings rate for 2015 is not yet available, but the FIES data suggest that we will see a rebound in savings in 2015 following the decline induced by the increase in the consumption tax in April 2014.

[Figure 3]

Figure 4 depicts the savings rates of the working age population in the FIES data by age group for the period 1990-2014 using five-year period averages. ${ }^{7}$ Because these are the savings rates for the same year for different age groups, the cohort effect is ignored. We note several interesting points. First, the savings rates of those aged in their $50 \mathrm{~s}$, immediately before the mandatory retirement age in most Japanese companies, were consistently higher than in their 40s in the 1990s. Second, judging from the 1990-94 and 1995-99 averages, the savings rates for all age groups increased. Some argue that this increase was because of the increase in precautionary saving by households facing increased labor market uncertainty (Murata 2003; Saito and Shiratsuka 2003; Ishihara and Doi 2004; Ishii 2009). However, the labor share also peaked around the second half of

\footnotetext{
${ }^{6}$ Previous studies exploring the sources of the dispersion between the GDP and FIES savings rates include Ueda and Ohno (1993), Iwamoto et al. (1995a, 1995b), Unayama (2010), and Iwaisako and Okada (2012).

7 The age brackets in the FIES changed after 2015, so we only compare broad age groups in previous years and those in 2015.
} 
the 1990s. Hence, an alternative explanation for the increase of household saving rates is that real wage had become too high in this period.

Third, between 1995-99 and 2000-04, the savings rate of the 50s age group significantly fell. This likely reflected the declining wages of this age group during this period amid the broader deterioration of Japanese employment conditions, particularly the seniority-based wage system. Further, as discussed below, the savings rate of the 60 years and over age group also declined sharply during this period. Lastly, we can see that there is no significant change in the savings rates for the other age groups in the 2000s, although the savings rates of those aged 55 to 59 years have decreased somewhat.

[Figure 4]

Figure 5 compares the savings rates of those aged less than 60 years and 60 years and over. As shown, both groups display a significant decline in the savings rate when using the FIES data from the end of the 1990s until 2004. This also reflects the deterioration of the Japanese labor market in the late 1990s and early 2000s as found earlier for the 60 to 64 years age group as well as those in their 50s. From 2006 to 2015, the savings rates of the working ages, i.e., those less than 60 years, rebounded significantly, with that for those aged 60 years and over also stopping to fall in 2006-11. However, elderly household saving rates declined again in 2012-14 (slightly rebounded in 2015). This decreasing trend in savings rates likely reflects the increasing share of the elderly in the Japanese population (those aged 65 years and over). Of course, there is a clear limit to our analysis using the semi-micro FIES data. For more detailed analyses of savings behavior and rates for this age group based on micro data, see Horioka (2010), Hori and Murata (2014), and Hori et al. (2015).

[Figure 5]

As shown in Figure 4 and 5, from the late 1990s to the mid-2000s, we observe large up and down movements in the age group saving rates based on the FIES data. These movements are mostly consistent with the behavior of the aggregate saving rates in the GDP data. This means that equally large fluctuations in the age group saving rates during this same period have greatly affected the rather turbulent movements of households saving rates in the last twenty years. Hence, if the aging population had been the main driving force behind the movement in the household savings rate, the aggregate savings 
rate should have declined more steadily and slowly.

What are the implications of these empirical facts? Given that the savings rate of the working age population in Japan almost fully rebounded in 2015, the adjustment to the negative income shocks of the early 2000 s of this age group is likely over. Hence, it is unlikely that we will observe another sharp decline in household savings rates as in the early 2000s in the near future, unless exposed to another large income shock. We do expect that the household savings rate will continue to decline, albeit very slowly.

\section{Household portfolios ${ }^{8}$}

In this section, we describe the pattern of Japanese household portfolios and their changes through the 2000s and 2010s. For our analysis, we use the micro survey data from Nikkei Radar, as also used in our previous work (Iwaisako 2009; Iwaisako, Mitchell, and Piggott 2005; Iwaisako, Ono, Saito, and Tokuda, 2015). ${ }^{9}$ Nikkei Radar is an annual survey of households residing in a metropolitan area within a $40 \mathrm{~km}$ radius from Japan Railway's Tokyo station, conducted by Nikkei Research Inc., in Tokyo, Japan. It contains information about household portfolio allocations, along with household characteristics such as age, income, and occupation. We use the 2000-14 surveys, representing in total about 40,000 households (2,500-3,000 households per year). Note that Nikkei Radar represents a repeated-cross section, not panel data. See the above references for further details.

\subsection{Household wealth}

Table 1 provides summary statistics of the Nikkei Radar data set. Figure 6 illustrates the gross and net financial wealth and the ratio of residential mortgages to gross financial wealth in Panel A, along with the corresponding figures from the aggregate flow of funds data in Panel B. As shown, the average household in the Nikkei Radar data is better off,

\footnotetext{
${ }^{8}$ Our analyses in this section update and extend our research in Iwaisako, Ono, Saito, and Tokuda, (2015). We appreciate Naohisa Hirakata's comments on our previous paper.

9 The formal name of Nikkei Radar is "Nikkei kinyu-kodo chosa NEEDS-RADAR".

URL: http://www.nikkei-r.co.jp/domestic/industry/radar/ (only Japanese documentation is available).
} 
in terms of income and wealth, than the national average. Note that some households in Nikkei Radar data choose not to answer the questions regarding the amount of borrowings, including residential mortgages. In addition, the proportion of households in Nikkei Radar with a residential mortgage is smaller than the national average.

[Table 1 and Figure 6]

As shown in Panel A of Figure 6, average gross and net financial wealth increased steadily from 2000 to 2014 , with an average annual growth rate of $3.1 \%$ for gross financial wealth and $7.6 \%$ for net financial wealth. We obtain qualitatively similar results in Panel $\mathrm{B}$ when we use the aggregate flow of funds data where gross financial wealth grows at $1.6 \%$ per annum and net financial wealth at $2.3-2.4 \%$ over the same period. The significant difference between the growth rates of gross and net wealth implies deleveraging has been progressed during this period, as represented by the declining trend in debt/financial wealth ratio in both panels. Such deleveraging will be partly explained by the slowdown in residential mortgage loan growth in this same period.

Figure 7 depicts the changes in Japanese household wealth by age group in Nikkei Radar data. As shown, the average growth rate of gross financial wealth is higher for older householders in the 2000s and the first half of the 2010s. For example, the average annual growth rate for household wealth over the period 2002 to 2014 is $2.6 \%$ for the $61-$ 70 age group, $2.1 \%$ for the 71 and over age group, $-1.6 \%$ for the 30 and under age group, and $1.4 \%$ for the $31-40$ age group. The average growth rate across all age groups is $3.3 \%$ and much higher than the growth rates for any of these individual age groups. Hence, population aging, i.e., the increasing share of wealthy elderly households, has also contributed to the steady increase in gross financial wealth.

[Figure 7]

\subsection{Household portfolio shares}

Figure 8 shows the changing household shares of financial assets, namely demand, time, and other deposits, bonds, stocks, mutual funds, and foreign currency-denominated assets. During 2002 to 2014, the share of demand deposits increased, but the share of total deposits decreased. Hence, time deposits and other deposits more significantly decreased. 
In contrast, the share of risky assets - the sum of stocks, mutual funds, foreign currency denominated assets - increased. Finally, the share of bonds increased from $1.2 \%$ in 2002 to $2.3 \%$ in 2008 and then decreased to $1.9 \%$ in 2014 . This movement is consistent with that for household Japanese government bond holdings in the flow of funds data, as discussed in Section 4.

[Figure 8]

Figure 9 shows the changing asset shares by age group. As for the changes in financial wealth, the changing shares in the portfolios of older households mostly drive the changes in the shares of financial assets during the period 2002-14. The shares of safe assets (deposits) and risky assets (stocks) are stable for householders aged 30 and under and 31-40. In contrast, those aged 61-70 and 71 and over significantly decreased their deposit shares and increased their stock shares. Elderly householders also increased their asset shares held in bonds up until 2008.

[Figure 9]

Some earlier studies (Ameriks and Zeldes 2004; Guiso, Galiassos, and Jappelli eds. 2002; Iwaisako 2009) found that the changes in stock shares with age can be mostly attributed to the decision whether to hold any stocks (the extensive margin), not to the adjustment of the shares of assets already in the portfolio (the intensive margin). In other words, the changing proportion of asset holders among all households in the same age group explains most of the changes in asset shares at the aggregate level. In Figures 10 and 11, we examine if this also holds for the Nikkei Radar data set. We first consider the extensive and intensive margins for stocks in Figure 10. Panel A details the extensive and intensive margin at the aggregate level. As shown, the population share of stockholders, i.e. the extensive margin, crept up during the 2000s and 2010s. However, the share of stocks within the portfolios of stockholders remains mostly unchanged. Panel B depicts the extensive margin by age group. As shown, the increase in the extensive margin is greater for older households (51 and over age group), while the extensive margins for younger households are either stable (31-40 and 41-50 age groups) or decreasing (30 and under age group) after the Global Financial Crisis in 2008-09. Figure 11 repeats the same exercise with the household bond holdings/shares. The change in the portfolio share of bonds also reflects the change in the extensive margin and the changes in the extensive margins of bonds are also greater for older households (those aged 51 and over). 
[Figure 10 and Figure 11 here]

To confirm the inferences in Figures 10 and 11, we conducted regression analysis of the effect of householder age on stock and bond holdings (the extensive margin) and the share of stock and bond holdings to gross financial assets (the intensive margin). The results are reported in Table 2. The main explanatory variables are dummy variables denoting householder age, for which the 30 years and under age group is set to the reference group. Other controls include the share of housing in gross total assets (RESIDENTIAL LAND/GROSS TOTAL ASSET), household income (INCOME), the value of gross total assets (GROSS TOTAL ASSET), the number of family members (FAMILYSIZE), and year dummies. ${ }^{10}$

[Table 2]

As reported in Panel A of Table 2, we identify the significant effects of age on stock holdings by households. In terms of the extensive margin, the probability of holding stocks is $10-16$ percentage points higher for households aged over 51 years relative to the reference group, the households aged 30 years and under. For the intensive margin, the share of stocks is 4-8 percentage points higher for households over 51 years of age. Hence, both the extensive and intensive margins are increasing with household age and both effects are statistically significant. However, the magnitude is much larger for the extensive margin. Compared with the results for stocks, the age effects on bond holdings are weaker. For the extensive margin, the probability of holding bonds is $2-5$ percentage points higher for households aged over 51 years compared with the reference group. There is no significant age effect for the intensive margin found for households' bond holdings.

The empirical results in Table 2 suggest that both risky asset shares and the share of the population holding any risky assets increase with age and barely fall by age, even for those households aged 60 years and over. This is consistent with our previous findings (Iwaisako 2009; Iwaisako, Ono, Saito, and Tokuda 2015) but is indeed an extreme result. Theoretically, classic studies by Merton (1969) and Samuelson (1969) found that there

\footnotetext{
${ }^{10}$ It is in general impossible to distinguish the impact of household aging from differences in asset demand across birth cohorts and from time-variant factors on asset demand (Ameriks, Zeldes 2004). By including year dummies as controls, we implicitly assume that the cohort effect is minimal.
} 
should be no systematic age-stock share relationship in a complete market. That said, professional financial advisors typically recommend that households take risks while they are young and gradually bring down their level of risky assets as they age (Canner, Mankiw and Weil 1997). To construct a theoretical model consistent with decreasing agerisky asset share pattern, some additional and reasonable assumptions such as imperfect risk sharing are then necessary for risky asset shares to decrease with age. See Campbell and Viceira (2002) for the review. Finally, empirical analyses for the US and Western Europe find that stock shares in household portfolios over the lifecycle exhibit a humpshaped distribution (Ameriks and Zeldes 2004; Guiso, Haliassos, and Jappelli, 2002).

What then would explain the not decreasing age-risky asset share pattern observed in Japanese household portfolios? As discussed in Iwaisako (2009), the relative importance of owner-occupied housing in housing wealth is a possible explanation. Many studies argue that owner-occupied housing is the primary source of the hump-shaped relationship between age and share of stock in household assets. ${ }^{11}$ The reason is that residential real estate is usually a large indivisible investment in the middle of the lifecycle which requires large down payments and subsequent mortgage loan repayments. This inhibits the ability of younger households to invest in risky financial assets such as stock and explains the hump-shaped relationship between risky asset share and household age.

Some additional characteristics in the Japanese economy perhaps push the peak of risky asset shares even further toward the terminal age. First, the age-income profile is steeper in Japan than in other developed countries. While the conventional seniority wage system has weakened in recent years, it remains for most core employees working for larger and older companies. Hence, those Japanese households purchase stocks only when they reach their 50s or with their retirement allowance. Second, the share of owneroccupied housing in total household wealth in Japan is much higher. This heavy mortgage burden after purchase inhibits household risk-taking for a longer period than elsewhere. As an additional explanation, Kitamura and Uchino (2011) argue that elderly households are more likely to be financially literate. A peer effect in stock investments among elderly households is yet another potential explanation.

Overall, it is not so difficult to provide explanations for why the stock shares of

\footnotetext{
${ }^{11}$ See Flavin and Yamashita (2002), Yamashita (2003), Cocco (2005), Yao and Zhang (2005), Chetty et al. (2016).
} 
Japanese households do not decrease, even for those aged over 60, but providing concrete evidence is much more difficult. In particular, the number of observations for households over 65 years is very small in Nikkei Radar and in most existing household surveys. Nevertheless, there is a clearly a need for more comprehensive analysis of the saving and portfolio behaviors of older households.

\section{Japanese government bond market}

The findings in the previous sections suggest there has been only a limited impact of population aging on Japanese household portfolios and asset markets. In particular, the retirement of Japan's baby boomers has not induced a portfolio shift from risky assets such as stocks to safe assets such as bank deposits or Japanese government bond (JGBs) so far. Nevertheless, we closely look at the JGB market data in this section and examine the changes in the holding pattern of JGBs in recent years.

Figure 12 plots the holdings and asset shares of JGBs for domestic (direct household only) and foreign investors using the aggregate flow of funds data. As shown in Panel A, household direct holdings of JGBs peaked in around 2008-09. However, direct holdings are very limited compared with the total amount of outstanding JGBs. Consequently, any adjustments in household portfolios should not have a significant effect on the JGB market as a whole. As shown in Panel B, foreign investor JGB holdings have steadily increased up until 2015. Who are these foreign investors? There is no data on current JGB holders, but transaction data suggest that most of this is by China-based investors, including China's sovereign wealth fund.

[Figure 12 here]

Since Abenomics began in late 2012, especially after the appointment of Haruhiko Kuroda as the Bank of Japan's governor, the holding structure of JGBs has greatly changed. The Bank of Japan purchased JGBs at an unprecedented rate for its Quantitative-Qualitative Easing (QQE) policy, which we clearly observe with the change in JGB holding structure from March 2011 to March 2016 depicted in Figure 13. As shown, previously the Bank of Japan's share of JGBs was less than $10 \%$, but has since increased to $32 \%$. Table 3 illustrates the changes in JGB holdings by type of investor. As 
shown, the Bank of Japan reduced its holdings of JGBs by $15.7 \%$ in the five years until 2010; in just the next five years, it increased its JGB holdings by $322 \%$ !

[Figure 13 and Table 3 here]

Elsewhere, financial institutions, particularly megabanks, have decreased their JGB holdings significantly since the start of Kuroda's QQE policy in 2013. As a result, the risks associated with a JGB price fall are concentrated among smaller financial institutions, including small regional banks, credit unions, and credit cooperatives. As for other investors, (life) insurance companies have been increasing their JGB holdings, but at a declining rate (from $36 \%$ in $2005-10$ down to $24 \%$ in 2010-15). Insurance companies have increased their holdings of JGBs, mostly at longer maturities as they care more about asset liability management than any potential capital loss arising from a fall in the price of JGBs.

Finally, Japan's the Government Pension Investment Fund Public (GPIF) made an historic shift in its portfolio allocation starting from October 2014, reducing its enormous JGB holding and doubling its holding of stocks as part of Abenomics. ${ }^{12}$ As a result public pensions' JGB holdings have decreased by $29 \%$ in the last several years.

\section{Conclusion}

This paper provides an overview of the impact of population aging on Japan's household savings and portfolio choices. Japan's household savings declined sharply in the early 2000s. However, as discussed in section 2, this decline reflects the sudden fall in labor income during this period, not population aging. As there is no expectation of an equivalent dramatic income decline in the near future, household savings will keep declining, but only very slowly. Corporate savings have been very high since the early 2000s. As a result, we observe only a decline in Japan's private sector savings as a percentage of GDP in the last 20 years of only about two percentage points.

\footnotetext{
12 "Japan's pension giant: Risk on", The Economist, Mar 15, 2014. URL:

http://www.economist.com/news/finance-and-economics/21599056-worlds-largest-pension-fundchanging-way-it-invests-big.

"Japan to approve GPIF boosting domestic stocks to 25 pct-sources" Reuters, Oct 30, 2014.

URL: http://www.reuters.com/article/us-japan-gpif-idUSKBN0IK01520141031.
} 
In Section 3, we closely examined the impact of aging on household portfolios. In the last twenty years, the share of stocks in household portfolios has moderately increased. The share of bonds increased until around 2008 and has since declined. These changes in asset shares are mostly the result of behaviors of elderly households in their 50s and over 60. Because portfolio choices by elderly Japanese differ from that of US households, the aging of the population has not induced an exit from the stock market so far. In fact, aging may well have induced risk-taking by Japanese households in the past 15 years. In section 4, we turn our attention to the JGB market. Although household holdings of JGBs peaked in around 2008-09, the household share of JGBs outstanding has always been small, so it will not have a significant effect on the JGB market in any way.

There are many important issues are left for future research. First, Japan's corporate savings have been extremely high, even compared with the United States after the Great Recession. Why it has been so and what we should do about it are important questions for both researchers and policymakers. Second, more through empirical investigations of older households' savings and portfolio behaviors of are needed. For example, more and more elderly, those aged over 60 years, are working these days compared with in 10 years ago. If this trend continues, will it increase the average income of elderlies in $60 \mathrm{~s}$ and early 70 s, so that increase their savings? If so, by how much? To answer such questions, we need a careful analysis of existing data and likely need to collect new data. This is because, in most existing household surveys, the numbers of observations of elderly households and particularly wealthy elderly households are very small. 


\section{References}

Abel, A.B. (2003) "The Effects of a Baby Boom on Stock Prices and Capital Accumulation in the Presence of Social Security." Econometrica 71:2, 551-78.

Ameriks, J., Zeldes, S.P. (2004) "How Do Household Portfolio Shares Vary with Age?" mimeo., Columbia Business School.

https://www0.gsb.columbia.edu/mygsb/faculty/research/pubfiles/16/Ameriks Zeldes age Sept 2004d.pdf

Ando, A., Modigliani, F. (1963) "The Life-Cycle Hypothesis of Saving: Aggregate Implications and Tests", American Economic Review 53: 55-84.

Ang A., Maddaloni A. (2005) "Do Demographic Changes Affect Risk Premiums? Evidence from International Data," Journal of Business 78(1), 341-380.

Bakshi, G. S., Zhiwu, C. (1994) "Baby Boom, Population Aging and Capital Markets." Journal of Business 67, no. 2: 165-202.

Campbell J.Y., Viceira, L.M., (2002) Strategic Asset Allocation: Portfolio Choice for Long-Term Investors. Oxford University Press.

Canner, N., Mankiw, N. G., Weil, D. N. (1997) “An Asset Allocation Puzzle.” American Economic Review 87: 1, 181-191.

Cocco, J. F., (2005) "Portfolio Choice in The Presence of Housing," Review of Financial Studies 18, 535-567.

Chetty, R., Szeidl, A., Sandor, L. (2016) "The Effect of Housing on Portfolio Choice", http://www.rajchetty.com/chettyfiles/housing_portchoice.pdf (earlier version: NBER Working Paper \# 15998).

Flavin, M, Yamashita, T. (2002) "Owner-Occupied Housing and the Composition of the Household Portfolio", American Economic Review 92, 345-362.

Geanakoplos, J., Magill, M., Quinzii, M. (2004) "Demography and the Long-Run Predictability of the Stock Market," Brookings Papers on Economic Activities: 1, 241-325.

Guiso, L., Haliassos, M., Jappelli, T. eds. (2002) Household Portfolios, MIT Press.

Hori, M, Iwamoto, K., Niizeki, T., Suga, F. (2015) “Do the Rich Save More in Japan? Evidence Based on Two Micro Datasets for the 2000s," ESRI Discussion paper series 322, Economic and Social Research Institute (ESRI).

Hori, M., Murata, K. (2014) "Is there a retirement consumption puzzle in Japan? Evidence based on panel data on households in the agricultural sector," CIS Discussion paper series 616, Center for Intergenerational Studies, Institute of Economic Research, Hitotsubashi University.

Horioka, C.Y. (2010) “The (dis)saving behavior of the aged in Japan," Japan and the World Economy 22, 151-158. 
Ishihara, H., Doi T. (2004) "1990-nendai no Nihon-ni okeru syouhi-chochiku kodo nitsuite (Consumption-saving behaviors in Japan in the 1990s: theoretical reconsideration and empirical analyses based on precautionary saving motive)", Keizai-bunseki (Economic Analyses) 174, ESRI, Cabinet Office.

Ishii, T. (2009) "Bubble kara Defure-ki ni kaketeno kakei-no yobiteki chochiku kodo no henka (Changing household saving behaviors based on precautionary motive from the bubble economy to the deflation period", in K. Fukao ed., Makuro-keizai to sangyo-kouzo (Macroeconomy and Industrial Structure), Keio University Press, 59-85.

Iwaisako, T. (2009) "Household portfolios in Japan", Japan and the World Economy 21:4, 373-382.

Iwaisako, T., Mitchell, O.S., Piggott, J. (2005) "Strategic Asset Allocation in Japan: An Empirical Evaluation", Pension Research Council WP2005-1, Pension Research Council, The Wharton School, University of Pennsylvania.

URL: http://papers.ssrn.com/sol3/papers.cfm?abstract_id=755031\#\#

Iwaisako, T., Okada K. (2012) "Understanding the decline in Japan's saving rate in the new millennium", Japan and the World Economy 24:3, 163-173.

Iwaisako, T., Ono, A., Saito, A., Tokuda, H. (2015) "Nihon-no Kakei-no Portfolio-sentaku: Kyojyu you fudosan ga kabusiki-hoyu ni ataeru eikyo (Residential property and household stock holdings: Evidence from Japanese micro data)”, Keizai-kenkyu (Economic Review) 66:3, 242-264.

Iwamoto, Y., Ozaki, T., Maekawa, Y. (1995a) "Kakei-chosa to Kokuminkeizai-keisan ni okeru Kakeichochiku-ritsu Doukou no Kairi ni tsuite (1): Gainen-no Soui to Hyouhon no Katayorino Mondai no Kentou (The discrepancy of saving rate behaviors in family income and expenditure survey and in GDP statistics: (1) differences in concept and sample bias)", Financial Review (Ministry of Finance), 34, 51-82.

Iwamoto, Y., Ozaki, T., Maekawa, Y. (1995b) “Kakei-chosa to Kokuminkeizai-keisan ni okeru Kakeichochiku-ritsu Doukou no Kairi ni tsuite (2): Micro Data to Macro Data no seigousei (The discrepancy of saving rate behaviors in family income and expenditure survey and in GDP statistics: (2) inconsistency between micro and macro data)", Financial Review (Ministry of Finance), 37, 82-112.

Jiang, H., Titman, S. Yamada, T. (2014) "Investor Composition and Liquidity: An Analysis of Japanese Stocks", mimeo., Available at SSRN 2129417.

Kitamura, Y. and Uchino, T. (2011) "Kakei-no shisan-sentaku-ni-okeru Gakureki-koka (The effect of academic background on household portfolio selection: evidence from Japanese repeated cross section data)" Kinyu-keizai kenkyu (Economic Review) 33, 24-45.

Merton, R. C. (1969), "Lifetime Portfolio Selection under Uncertainty: the Continuous-Time Case", Review of Economics and Statistics 51 (3): 247-257.

Modigliani, F., Brumberg, R. H. (1954) "Utility analysis and the consumption function: an 
interpretation of cross-section data", in K. K. Kurihara, ed., Post-Keynesian Economics, New Brunswick, NJ. Rutgers University Press. 388-436.

Murata, K. (2003) "Precautionary Saving and Income Uncertainty: Evidence from Japanese Micro Data," Monetary and Economic Studies, 21:3, 21-52, Institute for Monetary and Economic Studies, Bank of Japan.

Poterba, J.M. (1987) “Tax Policy and Corporate Saving,” Brookings Papers on Economic Activity: 2, 454-504.

Poterba, J.M. (2001) “Demographic Structure and Asset Returns," Review of Economics and Statistics, $83: 4,565-584$.

Poterba, J.M., Venti, S.F., Wise, D. A. (2015) "What Determines End of Life Assets? A Retrospective View," NBER Working Paper No. 21682

Saito, M., Shiratsuka, S., (2003) "Precautionary Motives versus Waiting Options: Evidence from Aggregate Household Saving in Japan," Monetary and Economic Studies 21:3, 1-20, Institute for Monetary and Economic Studies, Bank of Japan.

Samuelson, P. A. (1969) “Lifetime Portfolio Selection by Dynamic Stochastic Programming”, Review of Economics and Statistics 51:3, 239-246.

Ueda, K., Ohno, T. (1993) "Kakei-chochiku-ritsu Doukou no Nazo: Setai-chosa to Kokuminkeizaikeisan no Kairi ni tsuite (The puzzle of household saving rate: the discrepancy between survey data and GDP statistics)", Kinyu Kenkyu (BOJ Monetary Economic Studies), 12:2, 127-145.

Unayama, T. (2010) "SNA to Kakei-chosa no Chyochiku-ritsu no Kairi: Nihon-no Chyochiku-ritsu no Teika no Youin (Discrepancy between saving rates in SNA and family income and expenditure survey and its implications)", RIETI Discussion Paper Series 10-J-003, January 2010 (in Japanese). http://www.rieti.go.jp/jp/publications/dp/10j003.pdf.

Yamashita, T. (2003) "Owner-occupied housing and investment in stocks: an empirical test," Journal of Urban Economics 53: 2, 220-237.

Yao, R., Zhang, H.H. (2005) "Optimal Consumption and Portfolio Choices with Risky Housing and Borrowing Constraints", Review of Financial Studies 18:1, 197-239 


\section{Table 1: Nikkei Radar data 2000-14: summary statistics}

"Nikkei kinyu-kodo chosa NEEDS-RADAR" as known as Nikkei Radar is an annual survey of households conducted by Nikkei Research Inc., in Tokyo, Japan. Please refer to the beginning of section 3 for more detailed descriptions of the original data set.

Panel A: Basic statistics

\begin{tabular}{|c|c|c|c|c|c|c|c|c|c|}
\hline & \multicolumn{3}{|c|}{$\begin{array}{l}\text { Sample for the extensive margin } \\
\text { estimations }\end{array}$} & \multicolumn{3}{|c|}{$\begin{array}{l}\text { Sample for the intensive margin } \\
\text { estimation (Stock-holders) }\end{array}$} & \multicolumn{3}{|c|}{$\begin{array}{l}\text { Sample for the intensive margin } \\
\text { estimation (Bond-holders) }\end{array}$} \\
\hline & NOB & mean & std. dev. & NOB & mean & std. dev. & NOB & mean & std. dev. \\
\hline \multicolumn{10}{|l|}{ Dependent variables } \\
\hline STOCK_EX & 25,894 & 0.293 & 0.455 & & & & & & \\
\hline BOND_EX & 25,894 & 0.092 & 0.289 & & & & & & \\
\hline STOCK_SHARE & & & & 7,589 & 0.275 & 0.232 & & & \\
\hline BOND_SHARE & & & & & & & 2,374 & 0.188 & 0.171 \\
\hline \multicolumn{10}{|l|}{ Independent variables } \\
\hline AGE_31-40 & 25,894 & 0.235 & 0.424 & 7,589 & 0.145 & 0.352 & 2,374 & 0.099 & 0.298 \\
\hline AGE_41-50 & 25,894 & 0.236 & 0.425 & 7,589 & 0.219 & 0.414 & 2,374 & 0.180 & 0.385 \\
\hline AGE_51-60 & 25,894 & 0.194 & 0.395 & 7,589 & 0.246 & 0.431 & 2,374 & 0.222 & 0.416 \\
\hline AGE_61-70 & 25,894 & 0.165 & 0.371 & 7,589 & 0.259 & 0.438 & 2,374 & 0.324 & 0.468 \\
\hline AGE_71 AND OVER & 25,894 & 0.061 & 0.239 & 7,589 & 0.099 & 0.299 & 2,374 & 0.152 & 0.359 \\
\hline $\begin{array}{l}\text { RESIDENTIAL LAND/GROSS } \\
\text { TOTAL ASSET }\end{array}$ & 25,894 & 0.349 & 0.392 & 7,589 & 0.423 & 0.349 & 2,374 & 0.373 & 0.305 \\
\hline $\ln (\mathrm{INCOME})$ & 25,894 & 3.954 & 0.712 & 7,589 & 4.183 & 0.662 & 2,374 & 4.061 & 0.702 \\
\hline $\ln ($ GROSS TOTAL ASSET) & 25,894 & 4.573 & 1.849 & 7,589 & 5.716 & 1.189 & 2,374 & 6.029 & 1.031 \\
\hline FAMILYSIZE & 25,894 & 2.660 & 1.299 & 7,589 & 2.679 & 1.172 & 2,374 & 2.497 & 1.097 \\
\hline
\end{tabular}

Panel B: Age distribution in Nikkei Radar (Estimation sample)

\begin{tabular}{lccccccc}
\hline & \multicolumn{7}{c}{ Age of householder } \\
\cline { 2 - 8 } & $\begin{array}{c}30 \text { and } \\
\text { younger }\end{array}$ & $31-40$ & $41-50$ & $51-60$ & $61-70$ & $\begin{array}{c}71 \text { and } \\
\text { older }\end{array}$ & Total \\
\hline $2000-2004$ & 1,377 & 2,366 & 1,997 & 1,908 & 1,510 & 456 & 9,614 \\
& $(14.3 \%)$ & $(24.6 \%)$ & $(20.8 \%)$ & $(19.8 \%)$ & $(15.7 \%)$ & $(4.7 \%)$ & $(100.0 \%)$ \\
$2005-2009$ & 892 & 1,945 & 1,789 & 1,489 & 1,238 & 398 & 7,751 \\
& $(11.5 \%)$ & $(25.1 \%)$ & $(23.1 \%)$ & $(19.2 \%)$ & $(16.0 \%)$ & $(5.1 \%)$ & $(100.0 \%)$ \\
$2010-2014$ & 594 & 1,765 & 2,327 & 1,616 & 1,513 & 714 & 8,529 \\
& $(7.0 \%)$ & $(20.7 \%)$ & $(27.3 \%)$ & $(18.9 \%)$ & $(17.7 \%)$ & $(8.4 \%)$ & $(100.0 \%)$ \\
\hline Total & 2,863 & 6,076 & 6,113 & 5,013 & 4,261 & 1,568 & 25,894 \\
& $(11.1 \%)$ & $(23.5 \%)$ & $(23.6 \%)$ & $(19.4 \%)$ & $(16.5 \%)$ & $(6.1 \%)$ & $(100.0 \%)$ \\
\hline
\end{tabular}

STOCK_EX is a dummy variables which takes 1 if a household owned any stocks at all and 0 if it did not. STOCK_SHARE is the share of stocks in total financial wealth calculated only for households who own any stocks (i.e., if STOCK_EX=1). BOND_EX and BOND_SHARE are defined in the same manners for the household's bond holdings. For age dummies, we set households of age 30 and under as the reference group. AGE_31-40 is a dummy variable which takes 1 if a households head's age was between 31 and 40. Dummy variables for other/older age groups are defined in the same manner. 


\section{Table 2: Extensive and intensive margin for stocks and bonds: Nikkei Radar data}

Panel A: Probit estimation results for stock and bond holdings: Extensive margin

\begin{tabular}{|c|c|c|c|c|}
\hline \multirow[t]{2}{*}{ Estimation Method: Probit } & \multicolumn{2}{|c|}{$\begin{array}{l}\text { Dependent variable: } \\
\text { STOCK_EX }\end{array}$} & \multicolumn{2}{|c|}{$\begin{array}{c}\text { Dependent variable: } \\
\text { BOND_EX }\end{array}$} \\
\hline & $\mathrm{dy} / \mathrm{dx}$ & Std. Err. & $\mathrm{dy} / \mathrm{dx}$ & Std. Err. \\
\hline AGE_31-40 & $0.031^{* *}$ & 0.014 & 0.000 & 0.007 \\
\hline AGE_41-50 & $0.055^{* * *}$ & 0.015 & $0.012^{*}$ & 0.007 \\
\hline AGE_51-60 & $0.099^{* * *}$ & 0.016 & $0.017^{* *}$ & 0.008 \\
\hline AGE_61-70 & $0.154^{* * *}$ & 0.017 & $0.031^{* * *}$ & 0.009 \\
\hline AGE_71 AND OVER & $0.164^{* * *}$ & 0.020 & $0.054^{* * *}$ & 0.013 \\
\hline $\begin{array}{l}\text { RESIDENTIAL LAND/GROSS } \\
\text { TOTAL ASSET }\end{array}$ & $-0.299^{* * *}$ & 0.009 & $-0.116^{* * *}$ & 0.004 \\
\hline $\ln (\mathrm{INCOME})$ & $0.073^{* * *}$ & 0.005 & $-0.008^{* * *}$ & 0.002 \\
\hline $\ln ($ GROSS TOTAL ASSET) & $0.145^{* * *}$ & 0.003 & $0.050^{* * *}$ & 0.001 \\
\hline FAMILYSIZE & -0.002 & 0.003 & 0.001 & 0.001 \\
\hline YEAR dummies & YES & & YES & \\
\hline No. Obs. & 25,894 & & 25,894 & \\
\hline LR chi2 & 6592.87 & & 3362.48 & \\
\hline Prob $>$ chi 2 & 0.000 & & 0.000 & \\
\hline Pseudo R2 & 0.211 & & 0.212 & \\
\hline Log likelihood & -12366.481 & & -6252.967 & \\
\hline
\end{tabular}

Panel B: OLS estimation results for share of stock and bond holdings to gross financial assets: Intensive margin

\begin{tabular}{|c|c|c|c|c|c|c|}
\hline \multirow[t]{2}{*}{ Estimation method: OLS } & \multicolumn{3}{|c|}{$\begin{array}{c}\text { Dependent variable: } \\
\text { STOCK_SHARE }(>0)\end{array}$} & \multicolumn{3}{|c|}{$\begin{array}{l}\text { Dependent variable: } \\
\text { BOND_SHARE }(>0)\end{array}$} \\
\hline & Coeff. & & Std. Err. & Coeff. & & Std. Err. \\
\hline AGE_31-40 & 0.016 & & 0.017 & -0.026 & & 0.025 \\
\hline AGE_41-50 & 0.030 & * & 0.017 & 0.019 & & 0.025 \\
\hline AGE $51-60$ & 0.040 & $* *$ & 0.017 & 0.012 & & 0.024 \\
\hline AGE_61-70 & 0.051 & $* * *$ & 0.017 & 0.011 & & 0.024 \\
\hline AGE_71 AND OVER & 0.075 & $* * *$ & 0.018 & -0.002 & & 0.025 \\
\hline $\begin{array}{l}\text { RESIDENTIAL LAND/GROSS } \\
\text { TOTAL ASSET }\end{array}$ & 0.135 & $* * *$ & 0.009 & 0.101 & *** & 0.013 \\
\hline $\ln (\mathrm{INCOME})$ & 0.005 & & 0.005 & -0.018 & $* * *$ & 0.006 \\
\hline $\ln ($ GROSS TOTAL ASSET) & -0.048 & $* * *$ & 0.003 & -0.055 & *** & 0.004 \\
\hline FAMILYSIZE & -0.007 & $* * *$ & 0.003 & -0.001 & & 0.004 \\
\hline constant & 0.482 & & 18.760 & 0.548 & *** & 0.035 \\
\hline YEAR dummies & YES & & & YES & & \\
\hline No. Obs. & 7,589 & & & 2,374 & & \\
\hline F-value & 16.73 & & & 11.59 & & \\
\hline Prob $>$ F & 0.0000 & & & 0.0000 & & \\
\hline Adjusted R-squared & 0.0455 & & & 0.0931 & & \\
\hline Root MSE & 0.2263 & & & 0.1632 & & \\
\hline
\end{tabular}




\section{Table 3: Changes in JGB holding by investor type}

Numbers are tabulated from the data of JGB holding by investor type at the end of fiscal year (March). Original data source is Ministry of Finance's web page. URL:

http://www.mof.go.jp/jgbs/reference/appendix/

From 2005 to $2010 \quad$ From 2010 to 2015

\begin{tabular}{lcc}
\hline \hline Bank of Japan & $\triangle 15.7 \%$ & $322.4 \%$ \\
Financial institutions & $30.0 \%$ & $\triangle 30.0 \%$ \\
Insurance companies & $35.8 \%$ & $24.0 \%$ \\
Public pensions & $17.9 \%$ & $\triangle 28.7 \%$ \\
Private pensions & $15.6 \%$ & $20.7 \%$ \\
Foreign & $83.9 \%$ & $77.5 \%$ \\
Household & $11.3 \%$ & $\triangle 56.3 \%$ \\
Others & $100.4 \%$ & $\triangle 21.7 \%$ \\
General Government & $\triangle 70.3 \%$ & $\triangle 90.8 \%$ \\
TOTAL & $\mathbf{1 4 . 7 \%}$ & $\mathbf{1 8 . 2 \%}$
\end{tabular}


Figure 1: Japanese national savings (as percentage of GDP)

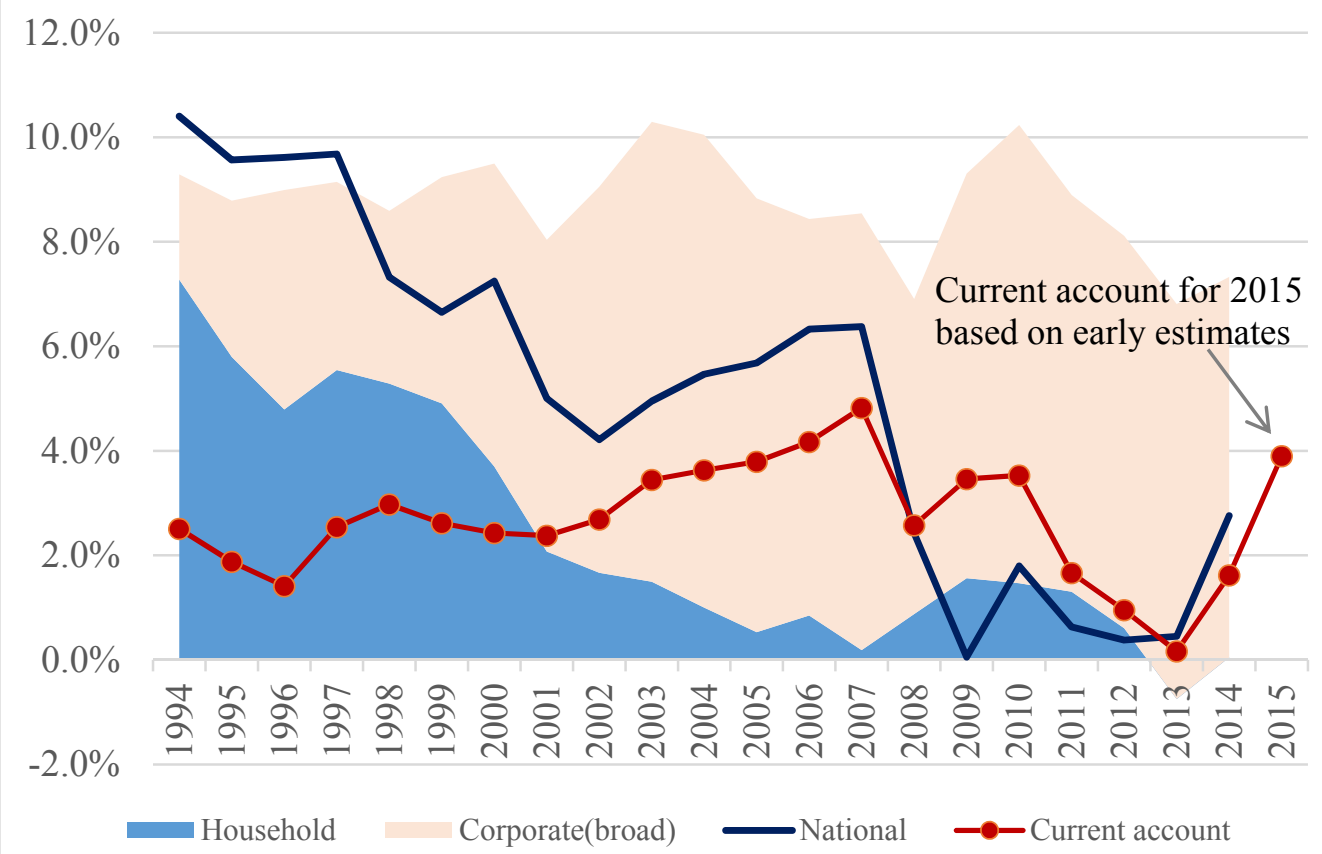

Data source: Cabinet Office's website (http://www.esri.cao.go.jp/en/sna/menu.html)

Figure 2: US national savings (as percentage of GDP)

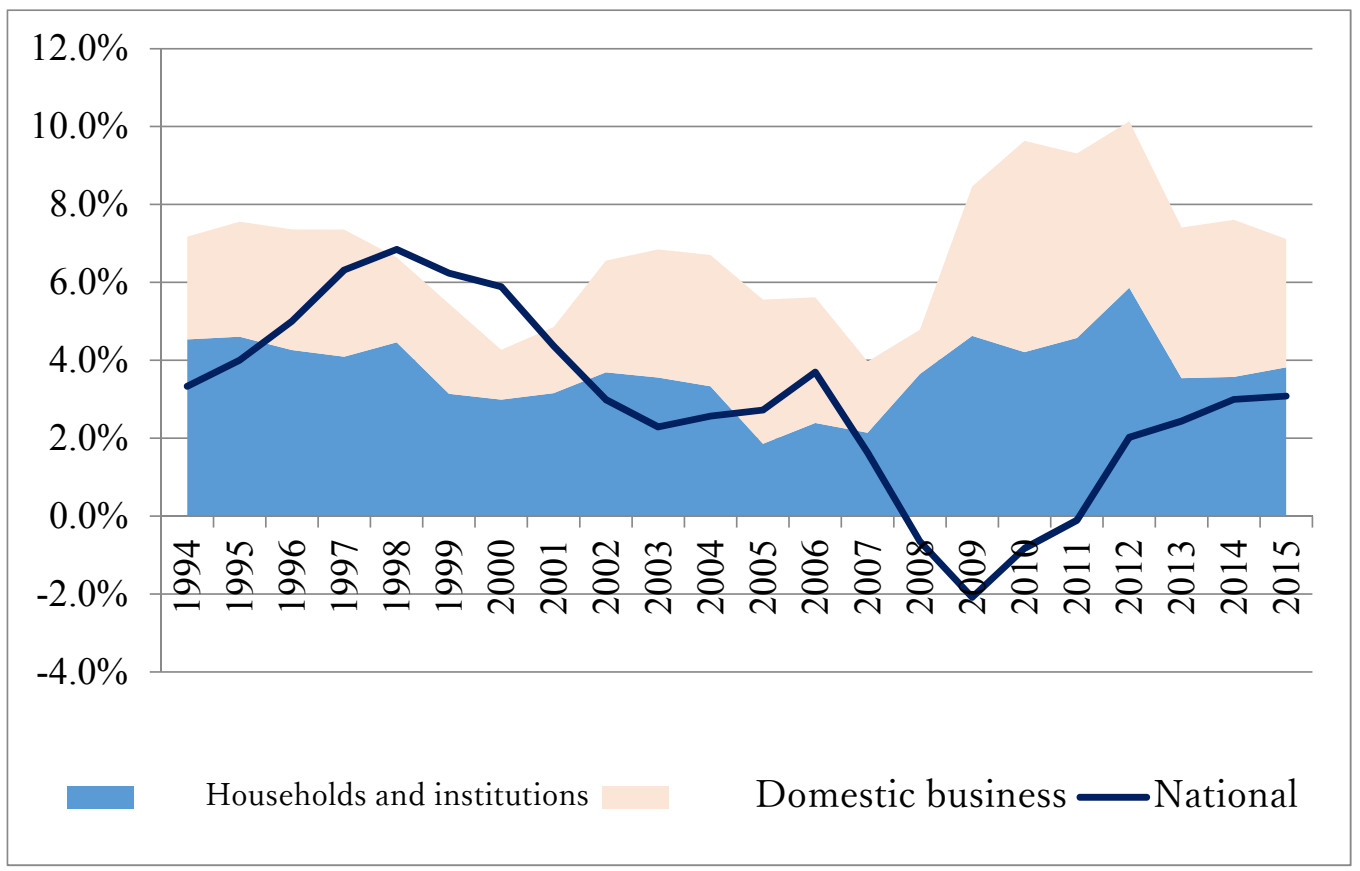

Data source: Bureau for Economic Analysis (http://www.bea.gov/national/Index.htm ) 
Figure 3: Japanese household savings rates:

GDP vs. Family Income and Expenditure Survey (FIES)

Data of Family Income and Expenditure Survey (FIES) are taken from the web sites Statistics Bureau, The Ministry of Internal Affairs and Communications (http://www.stat.go.jp/english/data/kakei/index.htm).

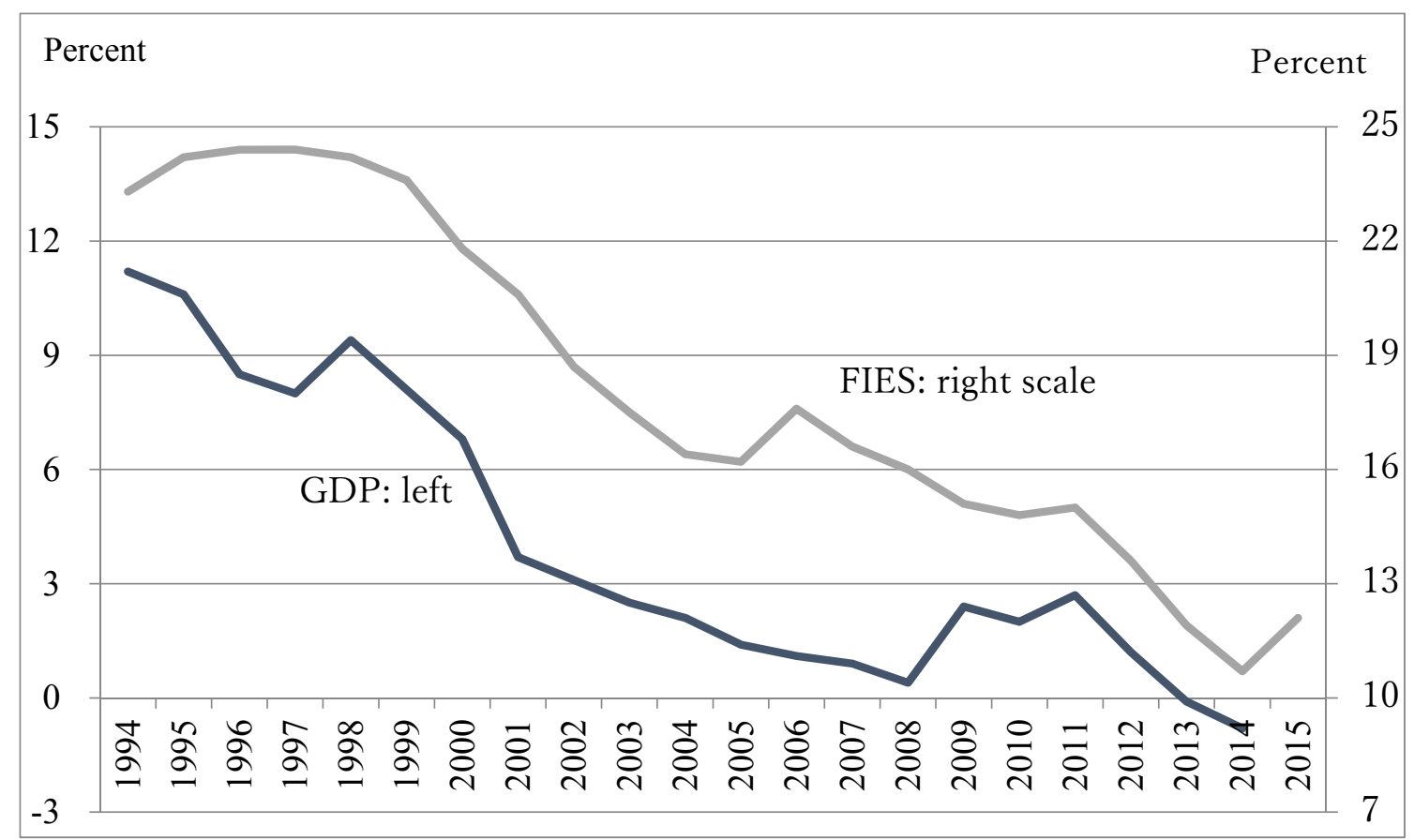


Figure 4: Age group savings rates in FIES data for working ages (5-year average)

Panel A: 1990-1994, 1995-1999, 2000-2004

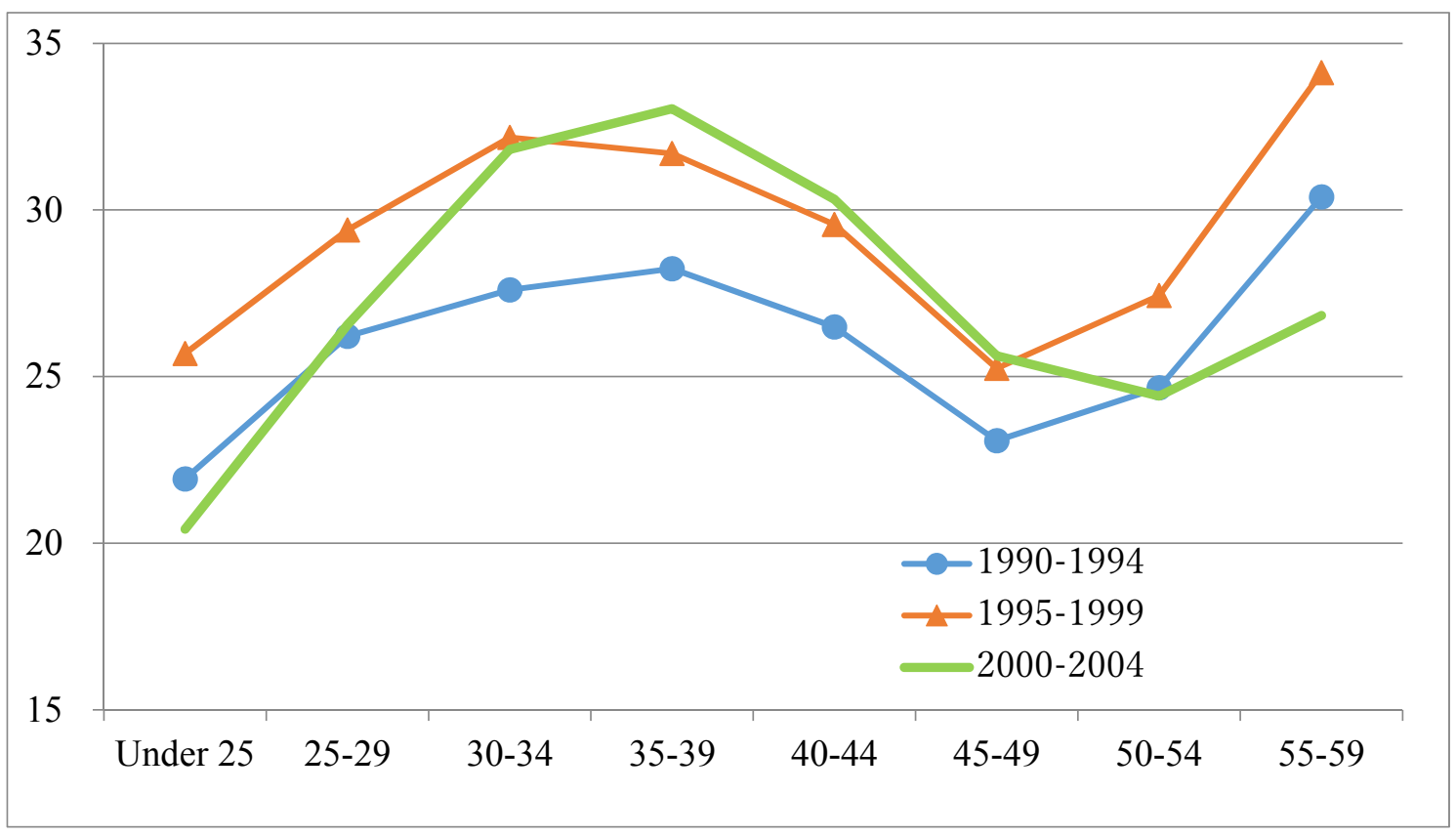

Panel B: 2000-2004, 2005-2009, 2010-2014,

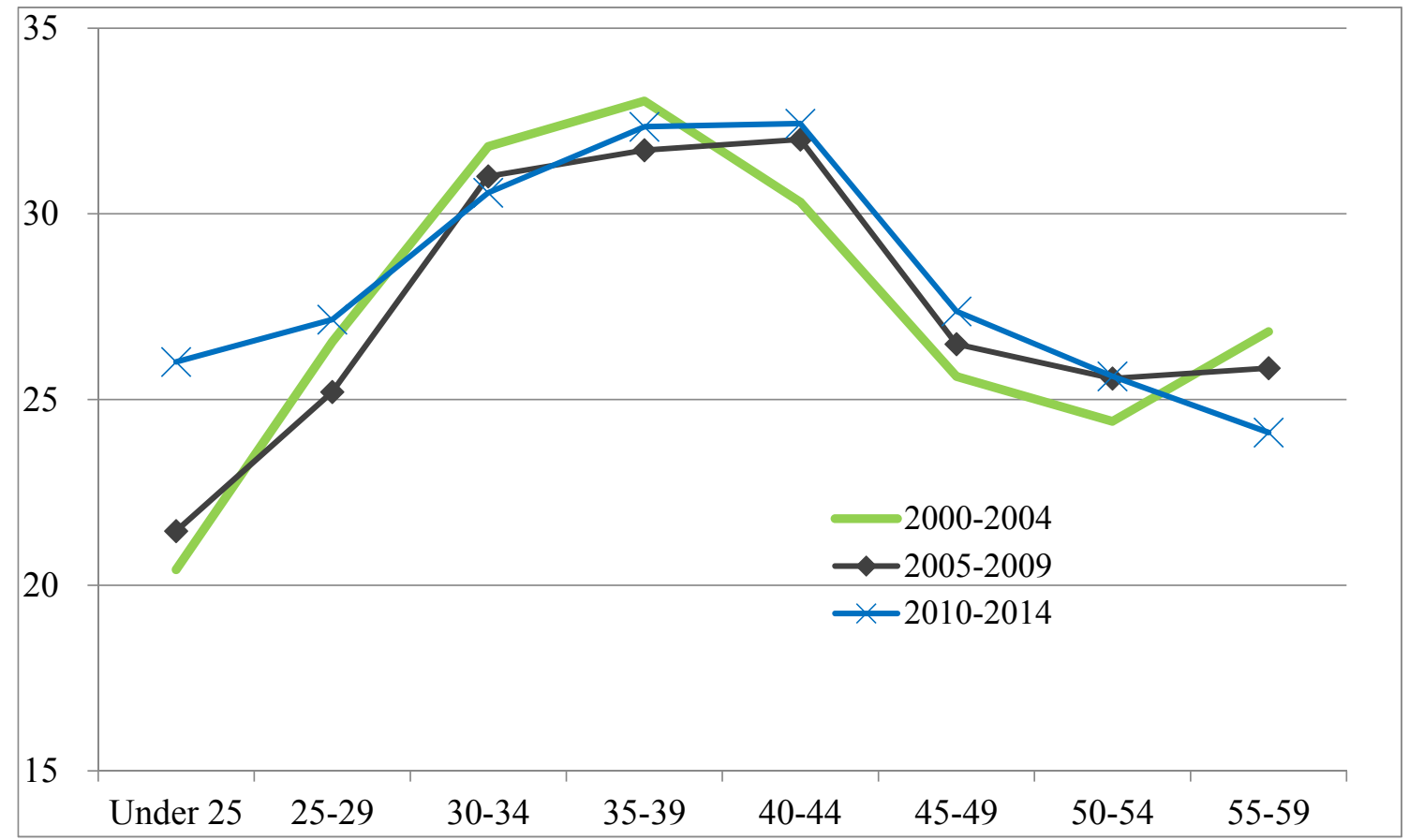


Figure 5: Age group savings rates in FIES data for working ages (under 60 years) and others (over 60 years)
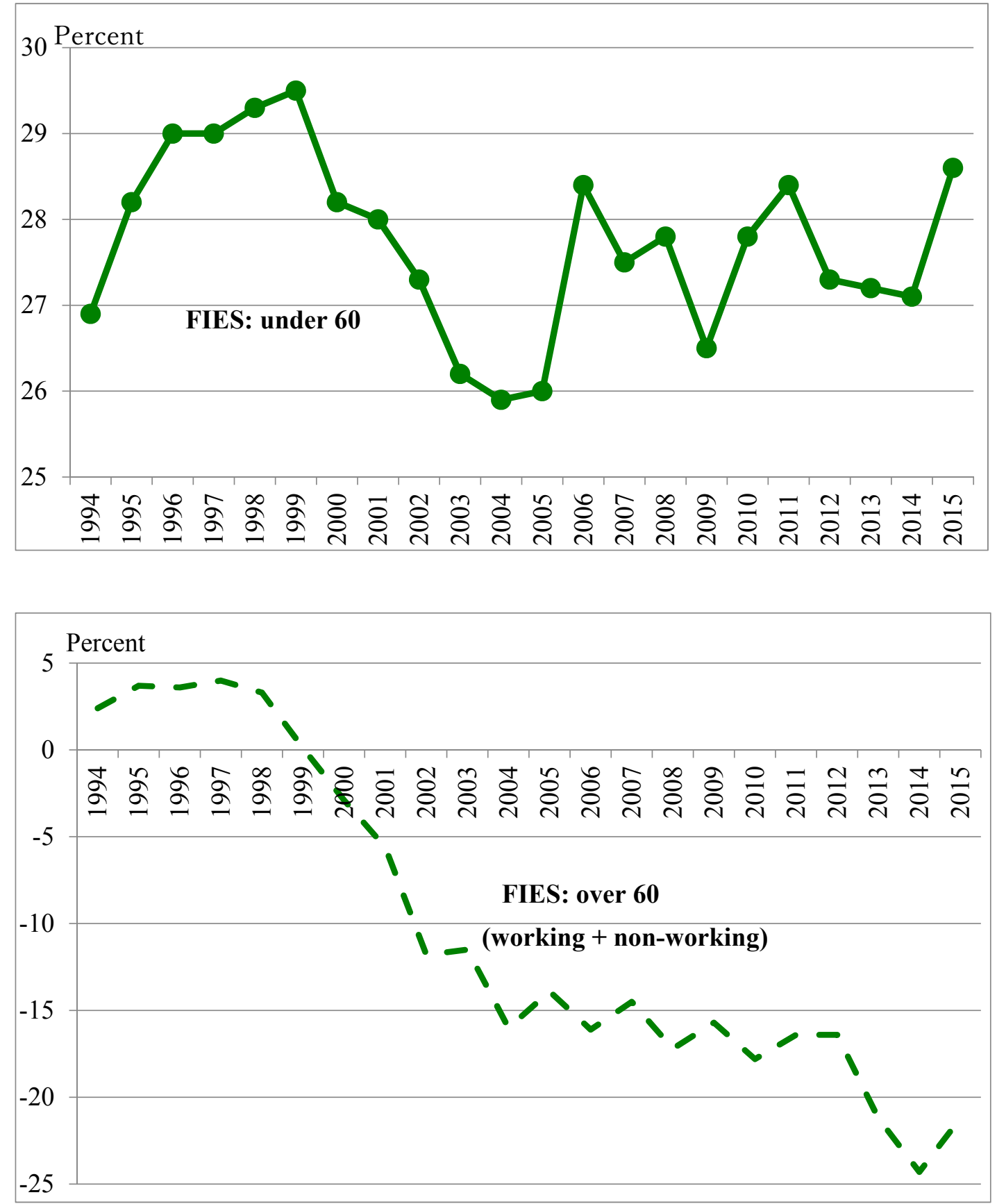


\section{Figure 6: Japanese household financial wealth}

Panel A: Nikkei Radar data (annual, mean)

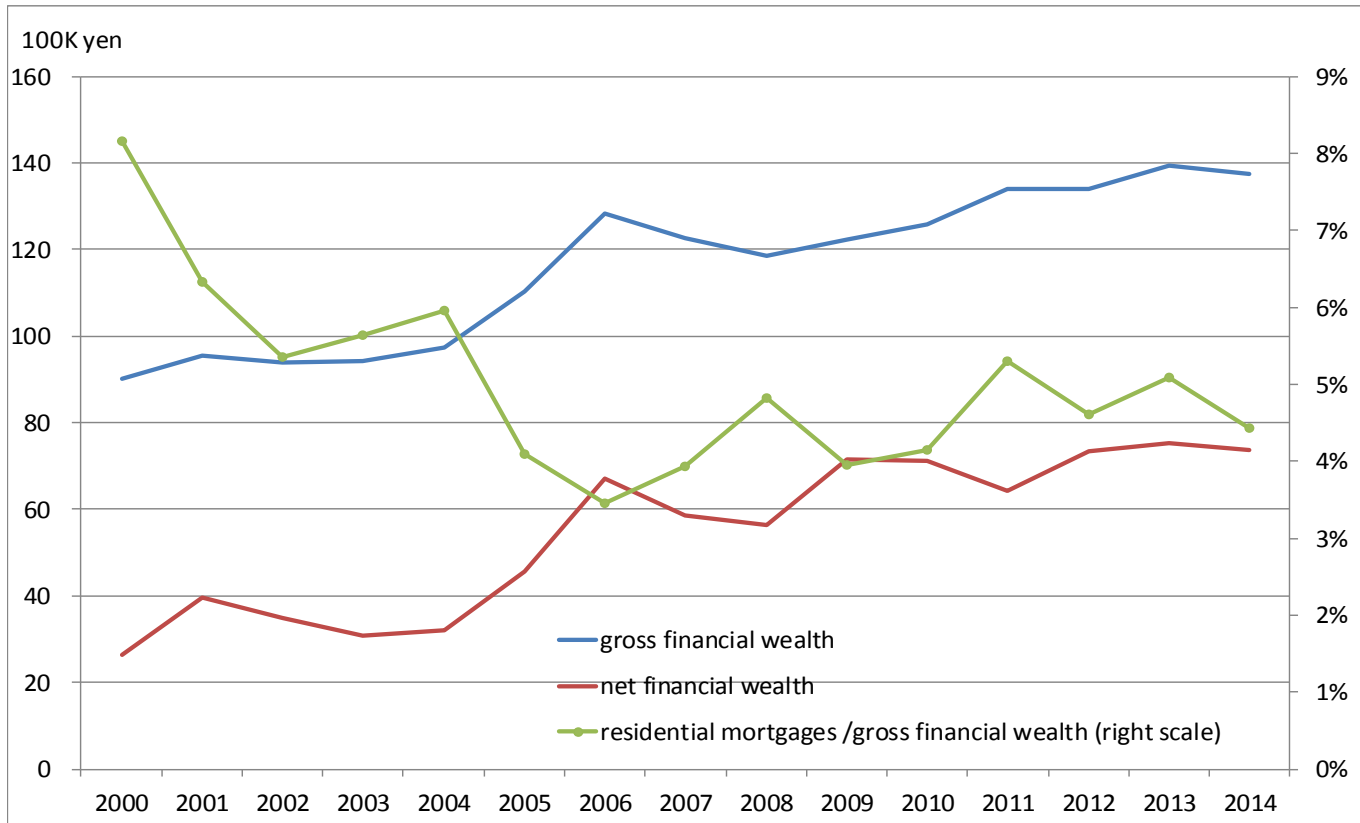

Panel B: Flow of funds data (quarterly)

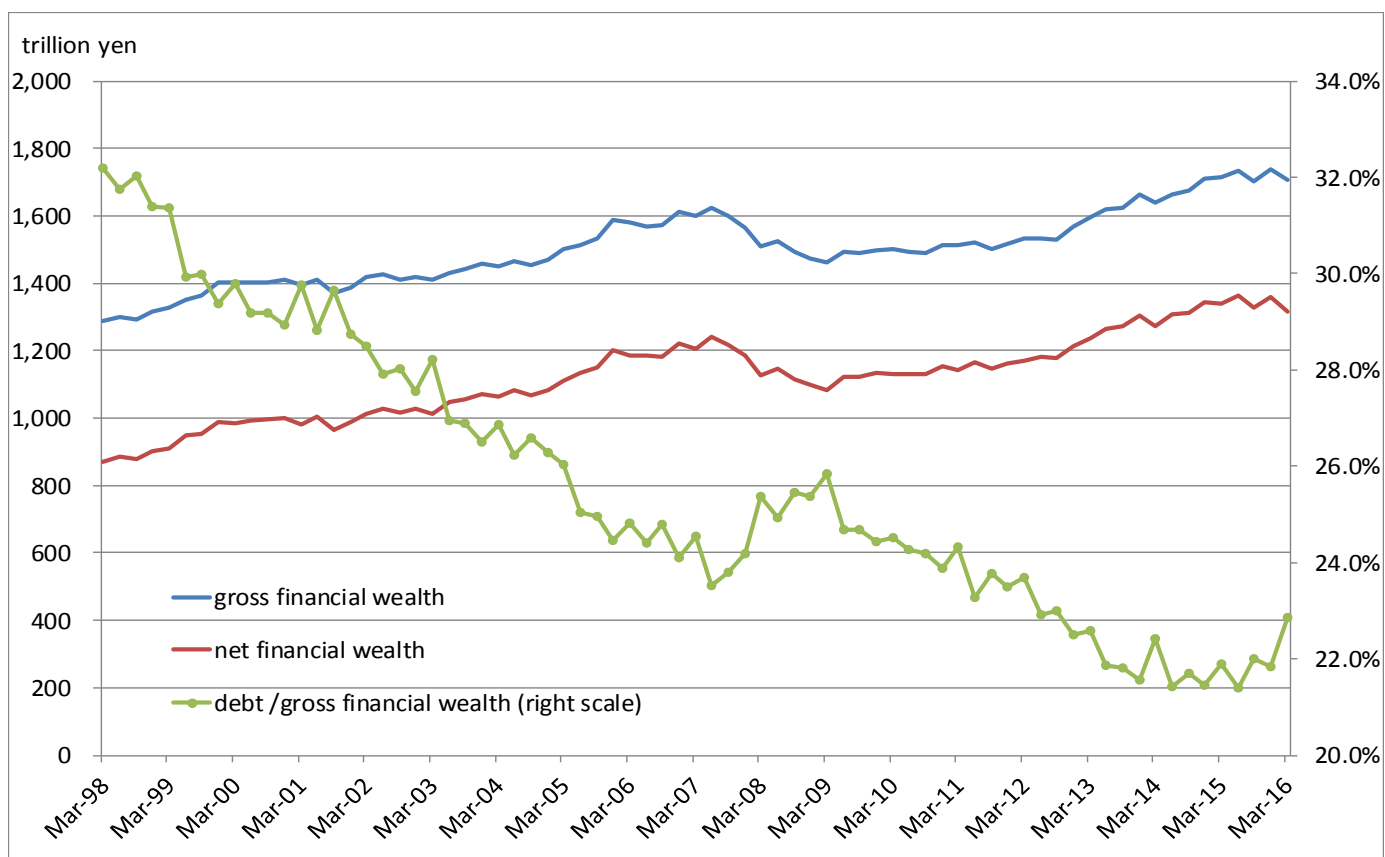

See the notes for Table 1 for the descriptions of Nikkei Radar data. Flow of funds data are taken from Bank of Japan's webpage (https://www.boj.or.jp/en/statistics/sj/index.htm/). 
Figure 7: Gross financial assets by age group

(three-year moving average: Nikkei Radar)

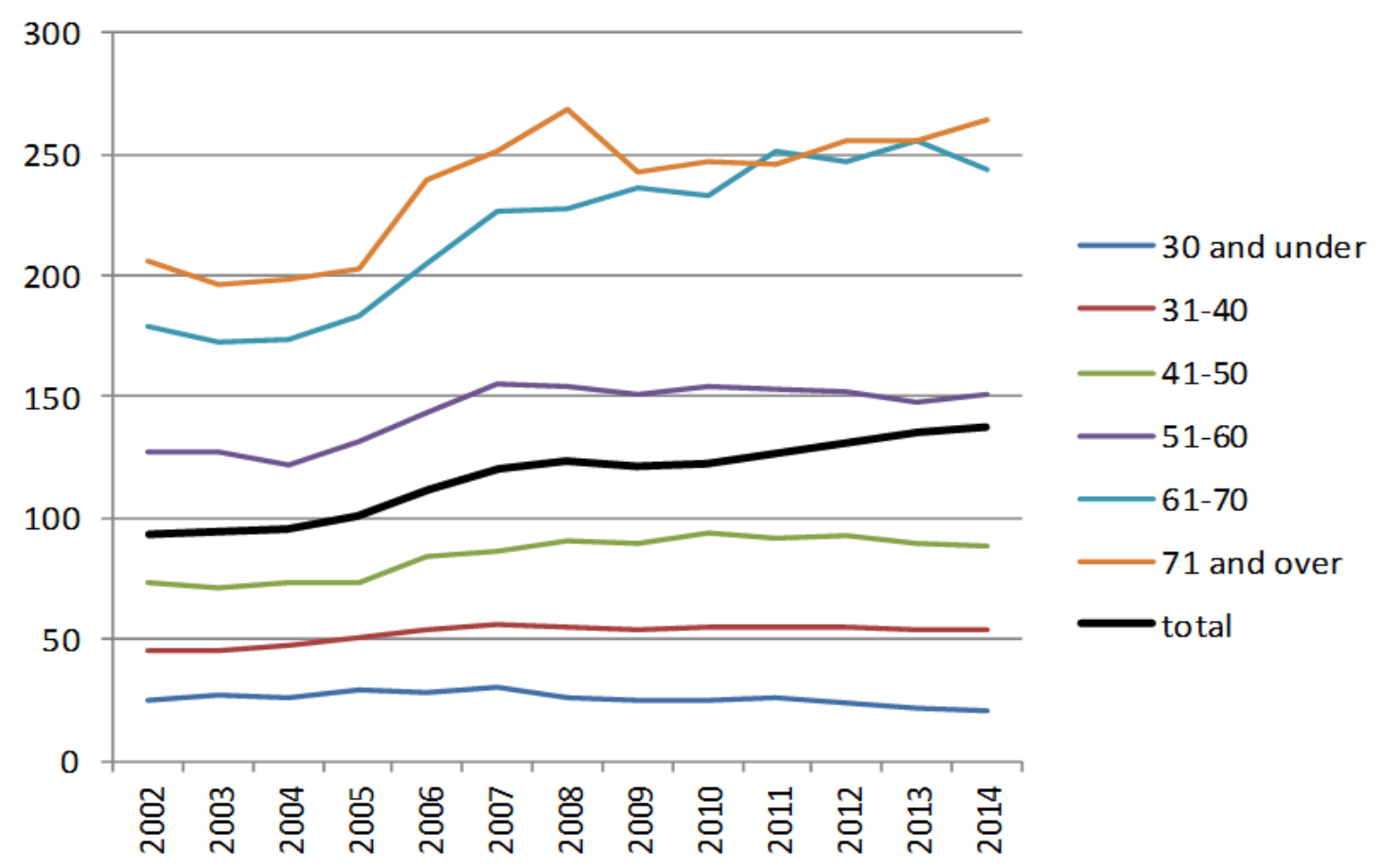

Figure 8: Shares of financial assets

(Nikkei Radar)

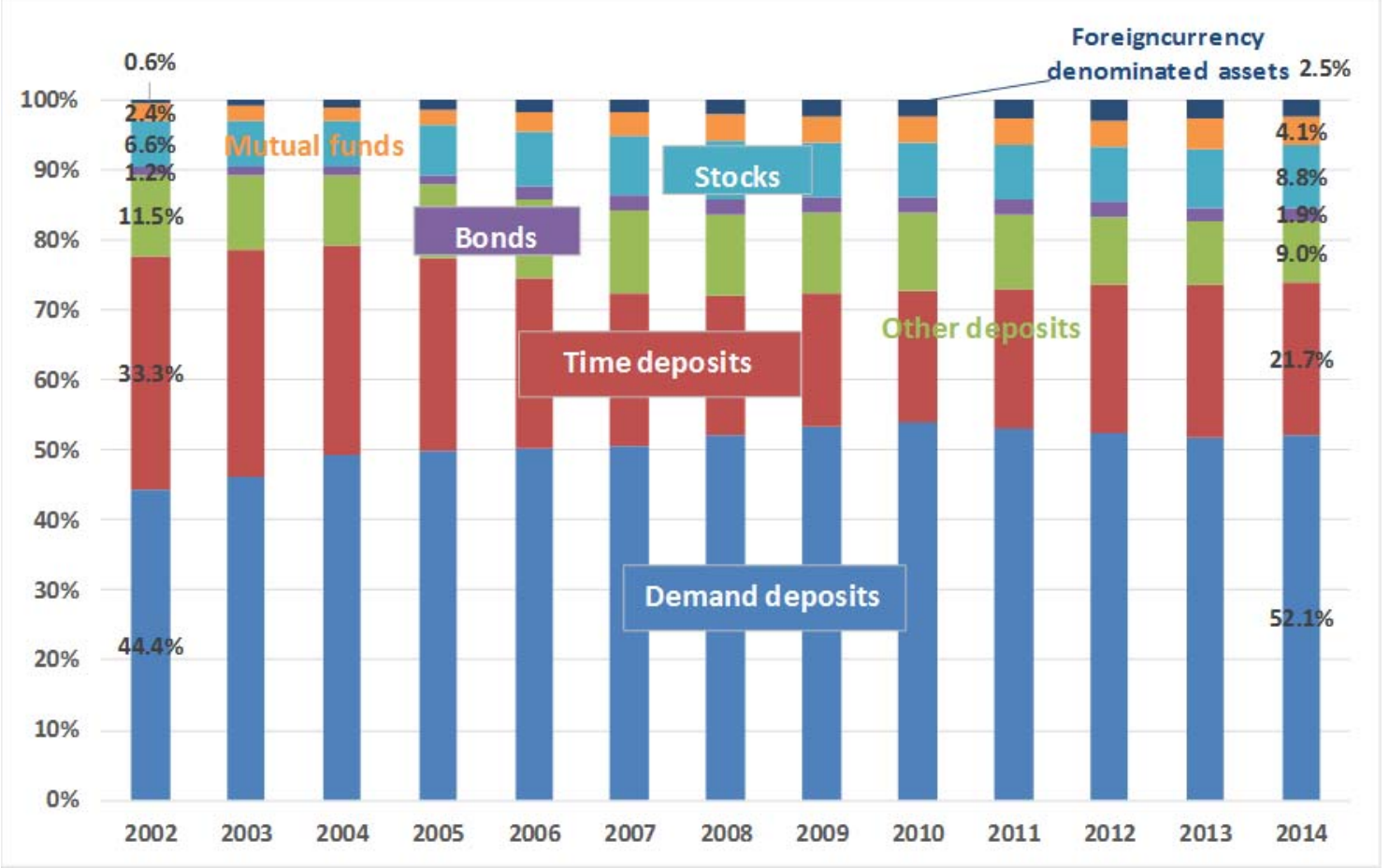


Figure 9: Share of financial assets by age group

(three-year moving average: Nikkei Radar)

\section{Panel A: Share of deposits}

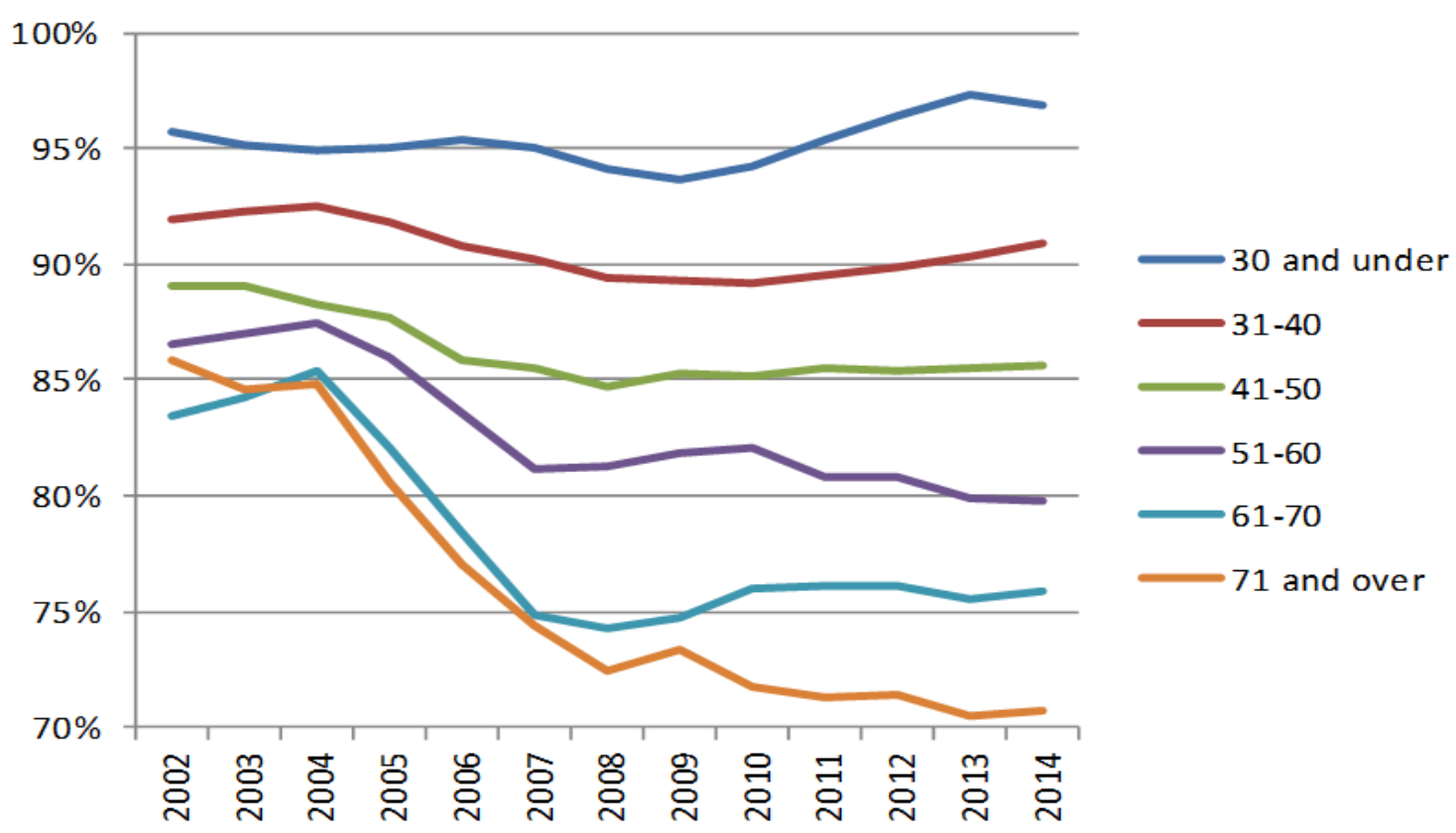

Panel B: Share of stocks

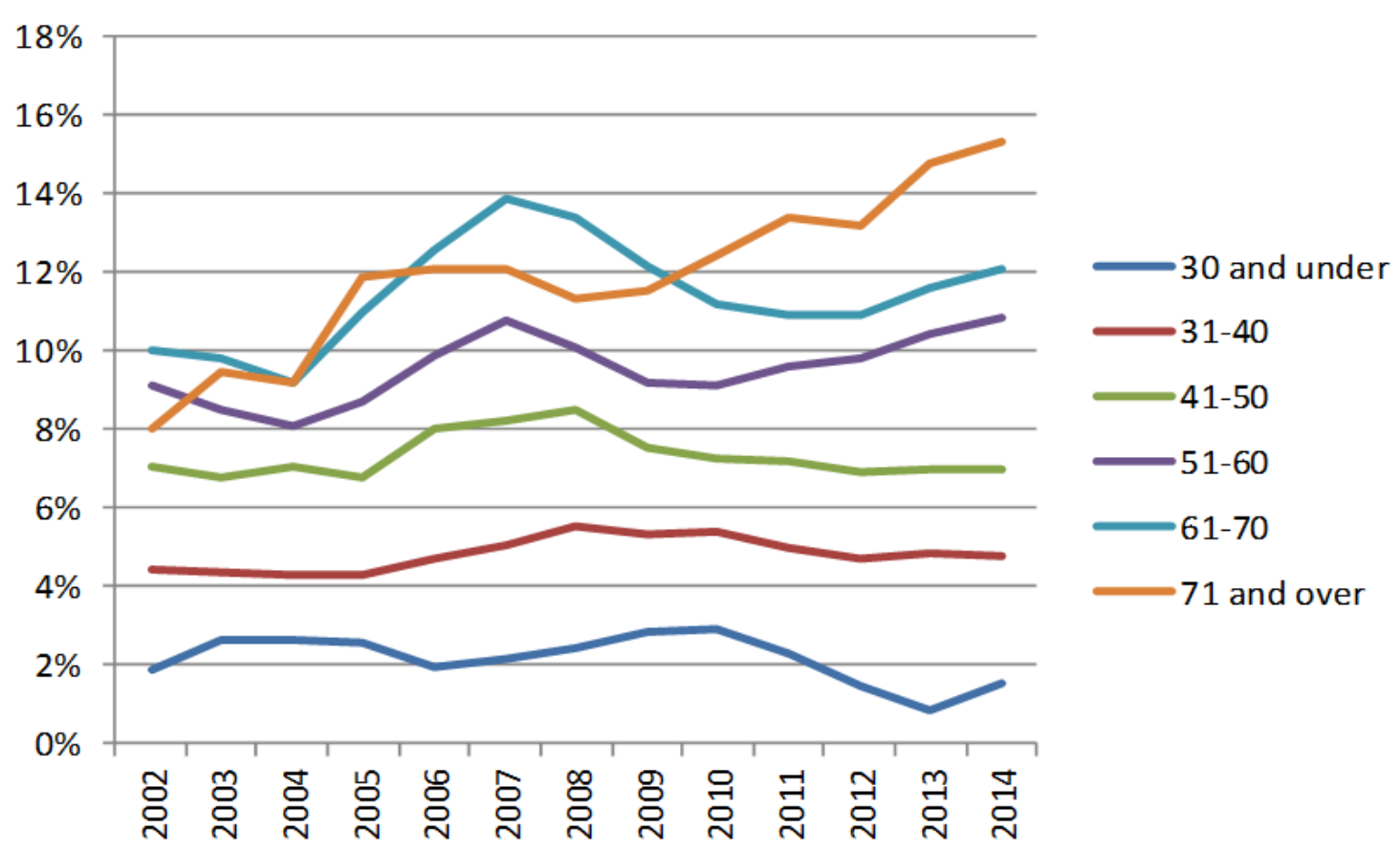


Figure 9 (continued)

Panel C: Share of bonds

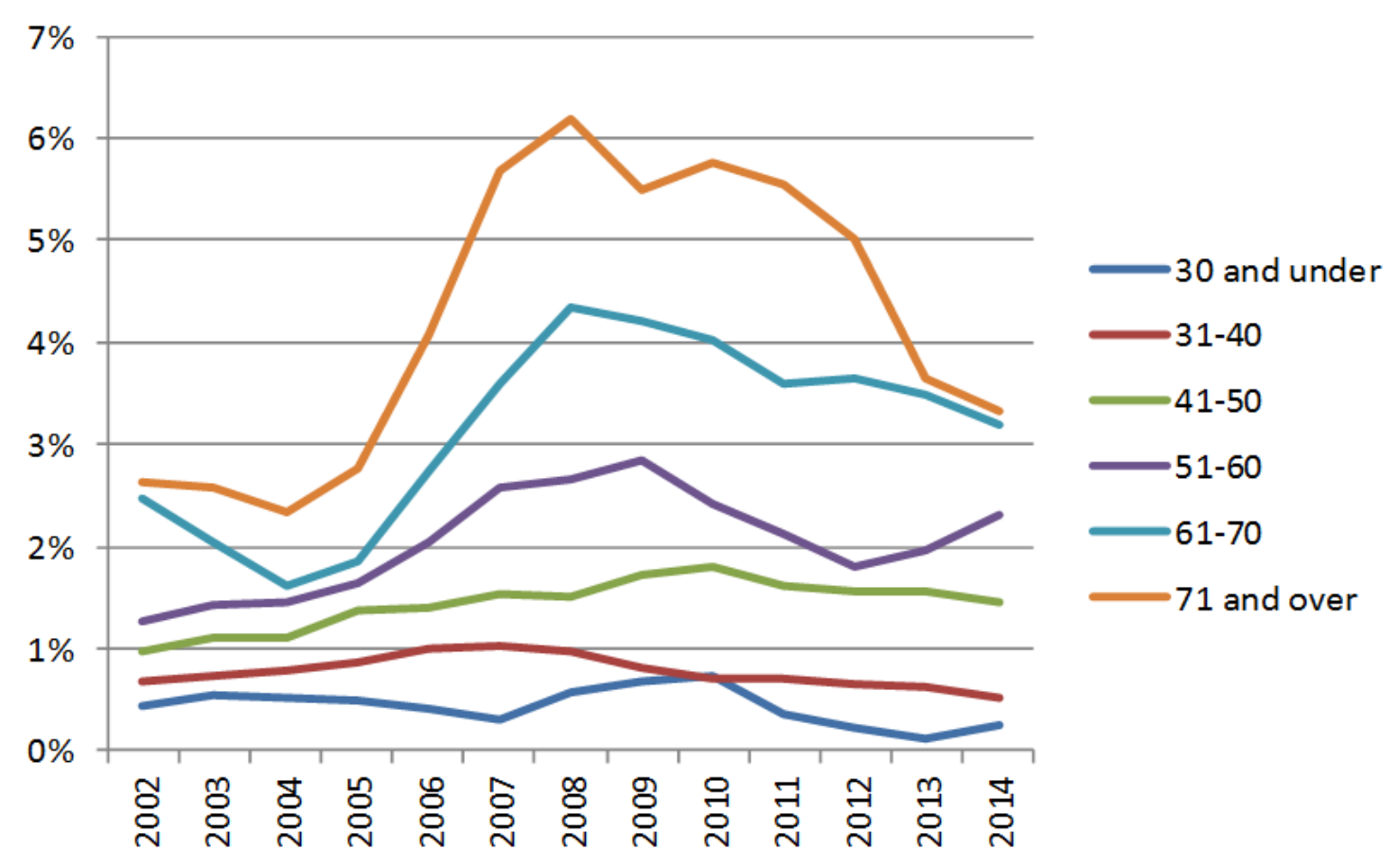




\section{Figure 10: Extensive and intensive margin: Stocks}

(3-year moving average: Nikkei Radar)

\section{Panel A: Extensive and intensive margin}

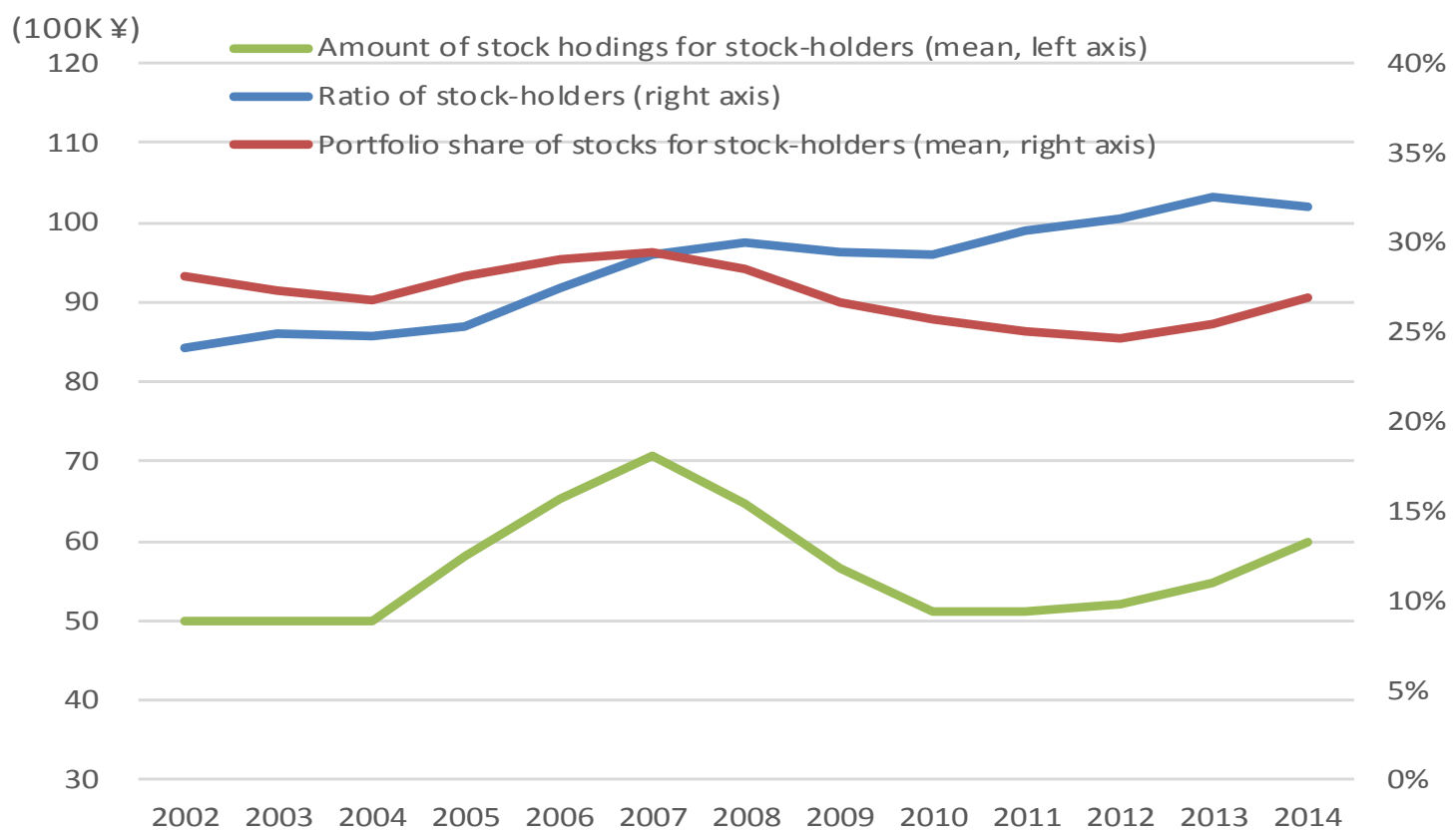

Panel B: Extensive margin by age group

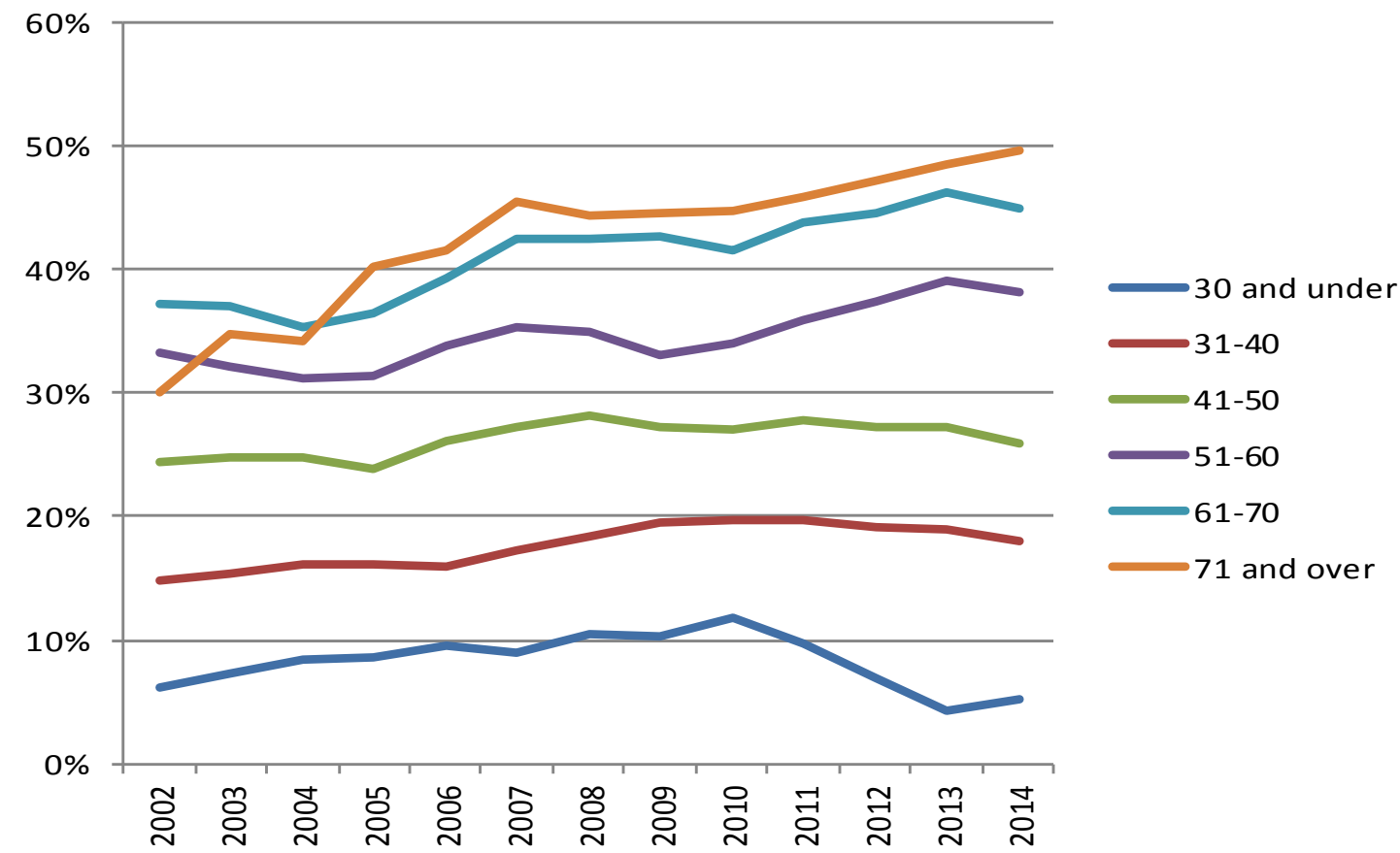




\section{Figure 11: Extensive and intensive margins: Bonds}

(3-year moving average: Nikkei Radar)

Panel A: Extensive and intensive margin

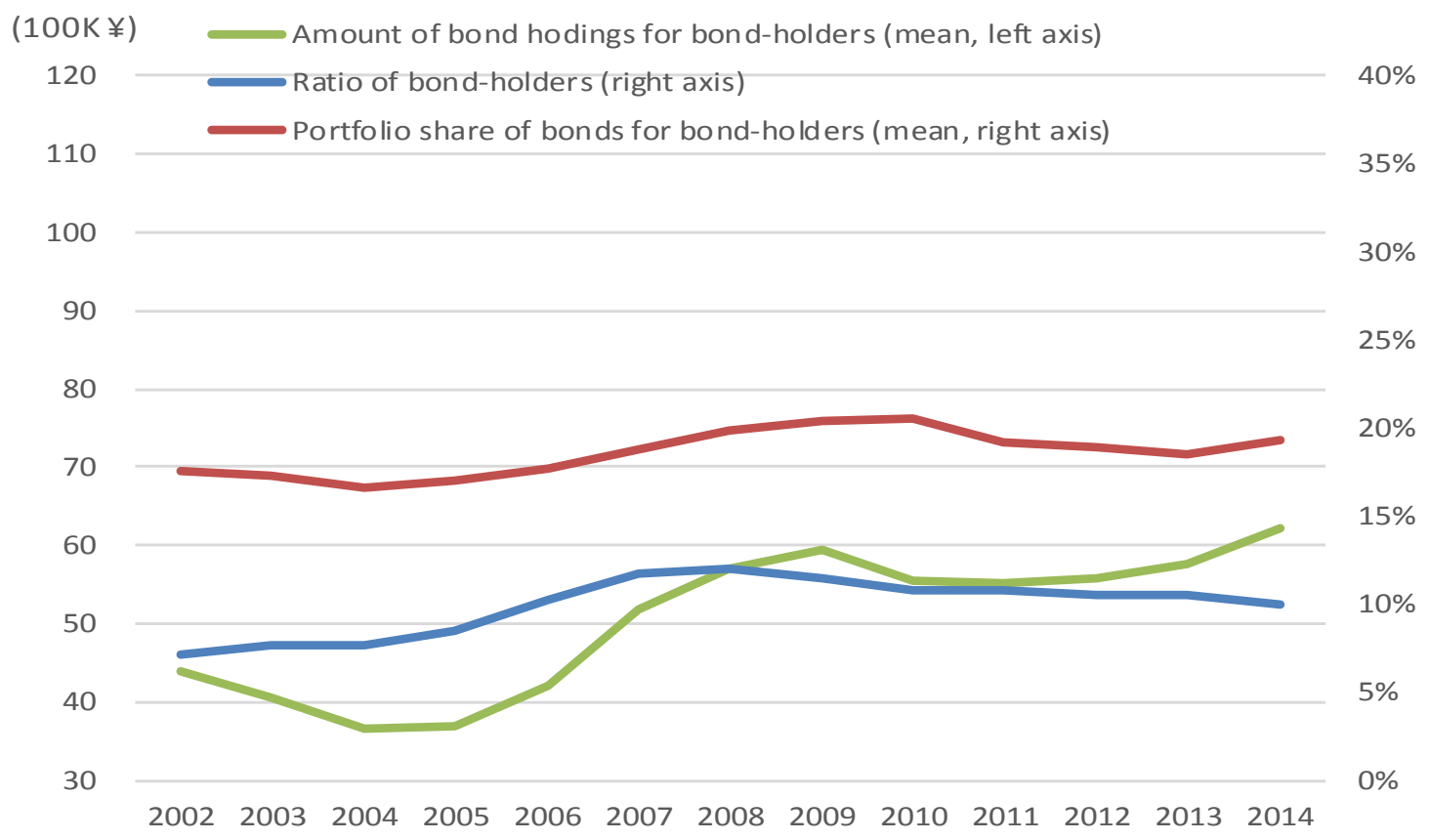

Panel B: Extensive margin by age group

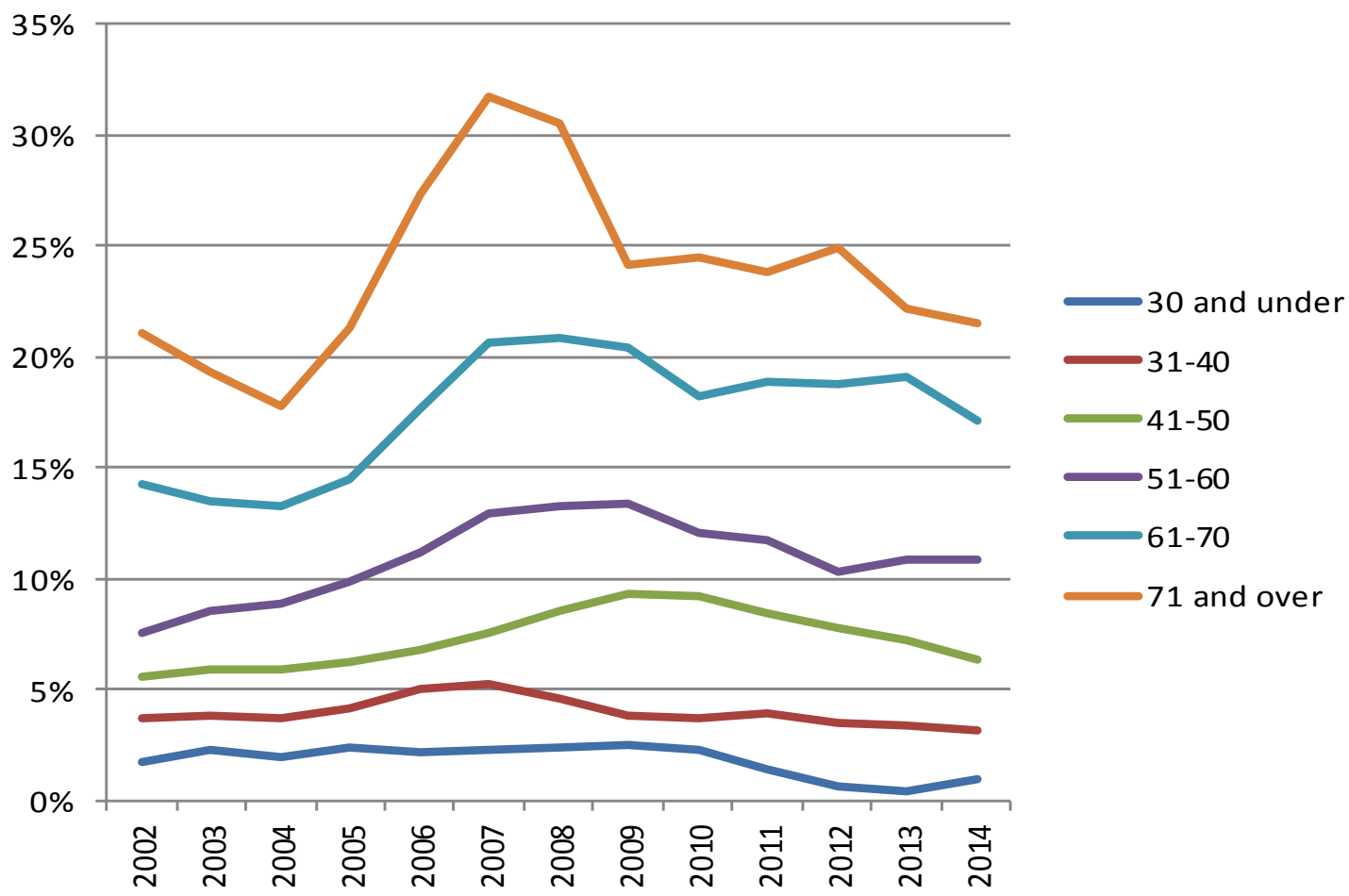


Figure 12: JGB holding data

Panel A: JGB holdings by Japanese households

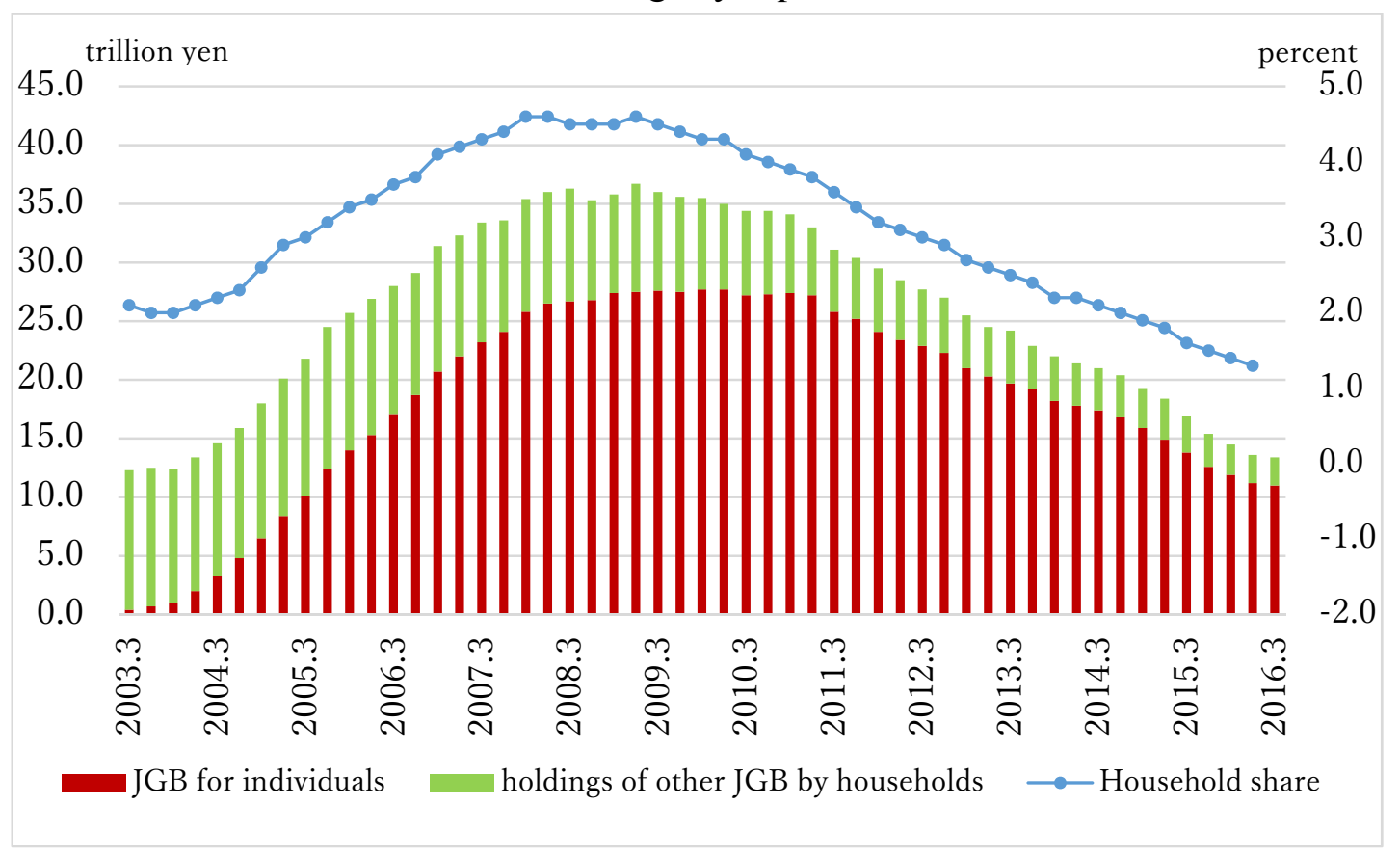

Panel B: JGB holdings by foreign investors

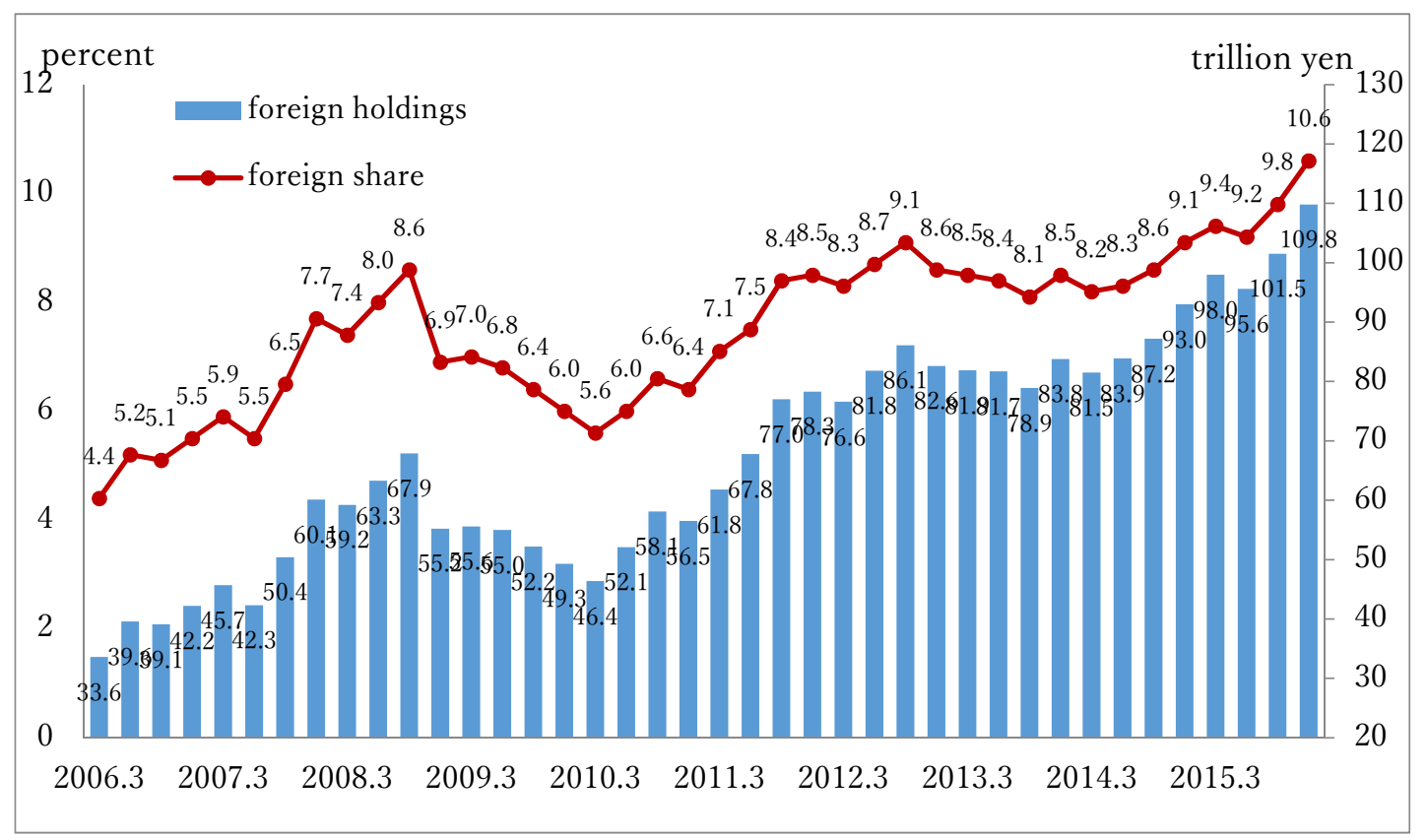

See notes for Table 3 for data sources. 
Figure 13: JGB holdings by type of investor: 2010 vs. 2015

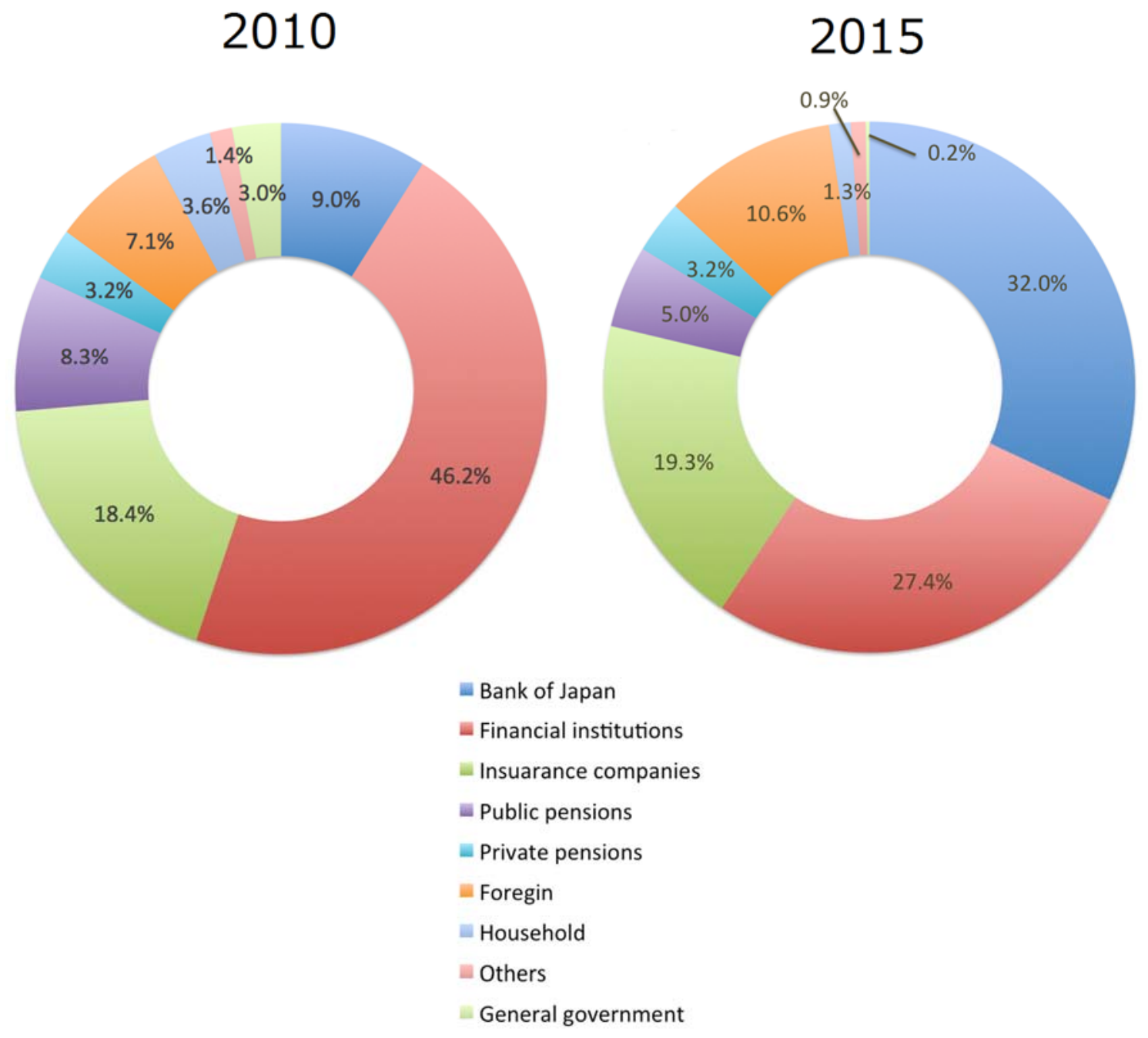

See notes for Table 3 for data sources. 